\title{
Soil Quality Assessment under Emerging Regulatory
}

\section{Requirements}

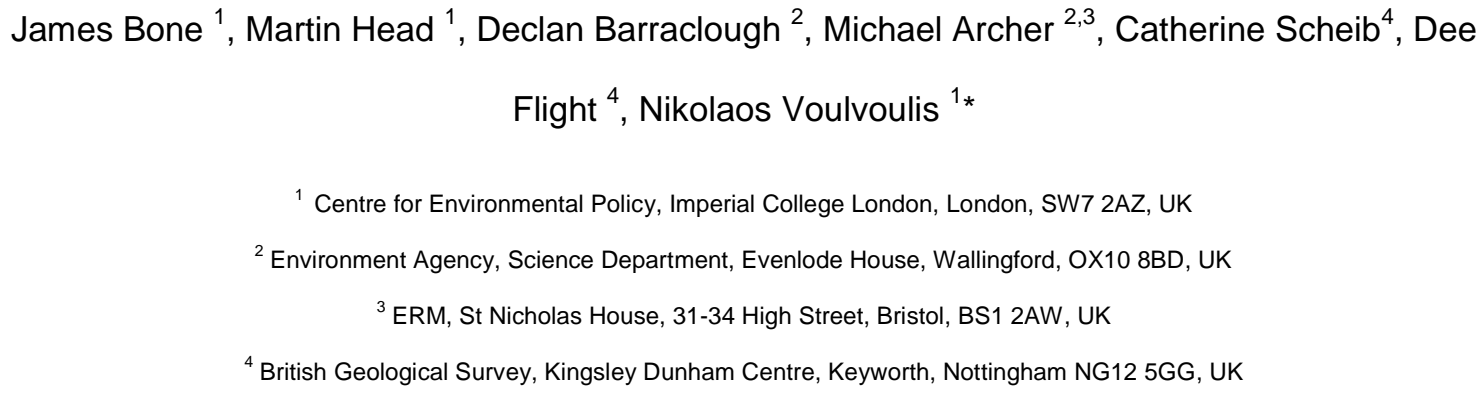

\section{Abstract}

New and emerging policies that aim to set standards for protection and sustainable use of soil are likely to require identification of geographical risk/ priority areas. Soil degradation can be seen as the change or disturbance in soil quality and it is therefore crucial that soil and soil quality are well understood to protect soils and to meet legislative requirements. To increase this understanding a review of the soil quality definition evaluated its development, with a formal scientific approach to assessment beginning in the 1970's, followed by a period of discussion and refinement. A number of reservations about soil quality assessment expressed in the literature are summarised. Taking concerns into account, a definition of soil quality incorporating soil's ability to meet multifunctional requirements, to provide ecosystem services, and the potential for soils to affect other environmental media is described. Assessment using this definition requires a large number of soil function dependent indicators that can be expensive, laborious, prone to error, and problematic in comparison. Findings demonstrate the need for a method that is not function dependent, but uses a number of cross functional indicators instead. This method to systematically prioritise areas where detailed investigation is required, using a ranking based against a desired level of action, could be relatively quick, easy and cost effective. As such this has potential to fill in gaps and compliment existing monitoring programs and assist in development and implementation of current and future soil protection legislation.

Keywords: Soil; Soil Degradation; Soil Quality; Soil Function; Environmental Monitoring; Indicators; EU Environmental Policies for Soil Protection;. 
Soil is relatively complex compared to other environmental media. The complexity is confounded by its spatial heterogeneity both over the Earth's land surface but also with depth. Soil is a continuum covering the earth's surface, not a discrete set of entities, and most soil is below ground and not readily visible (Buol et al. 2003). The complexity of the natural systems is manifested in the subject of soil science, which involves the study of complicated interrelated and interdependent processes (Shainberg 2000). Soil science is interdisciplinary and includes soil physics, soil chemistry, soil pedology, and soil biology.

Soil degradation is the long term decline in soil's current or future productivity and its environment moderating capacity (Lal 1994; Lal 1997; Lal 2001; Oldeman 1988). The main soil degradation processes include soil erosion by water and wind, development of extreme soil reaction (acidification, salinisation/alkalization), physical degradation (structural destruction, compaction, extreme moisture regime), biological degradation, unfavourable changes in the nutrient regime, decrease of buffering capacity, and contamination from natural or anthropogenic sources (Blum 1997; Várallya 1989). Major threats for soil in Europe, highlighted in the EU soil thematic strategy, are erosion, decline in organic matter, local and diffuse contamination, sealing, compaction, decline in biodiversity, salinisation, floods and landslides (European Commission (EC) 2006b). Soil degradation normally signifies a change or disturbance of soil quality, implying decline in quality and capacity of soil through natural or anthropogenic perturbations (Johnson et al. 1997; Lal 2009).

There is a move toward protection of soils to the same extent as water and air and to promote sustainable use of soil (Blum 2003; Quevauviller and Olazabal 2003). This increased importance of soil in environmental disciplines has occurred for a number of reasons. The drivers for this rise has been a proliferation of contaminated land legislation, soil geography and soil-geographical zoning, agricultural soil management zone identification, and environmental impact assessments and strategic environmental assessment taking into account soil quality, their characterisation and management (Fleming et al. 2000; Glasson et al. 2005; Nathanail and 
Bardos 2004; Urusevskaya 2007; Wood 2003). Soil is the basis of economic and cultural activities; however the economic value of soil has not adequately been recognised (Görlach et al. 2004). Due to the fundamental link between soil and the economy there are many economic activities that depend both directly and indirectly on soil quality including agriculture, industry and tourism. These economic activities could benefit from development of soil quality assessment methods, action prioritisation systems, and more generally from sustainable soil use and conservation.

Countries including the USA, Japan, Canada, Australia, Brazil and a number of developing countries have established soil protection policies (European Commission (EC) 2006a). Legislation aiming to protect soils in Europe includes the soil thematic strategy (European Commission (EC) 2006b), and the proposed soil framework directive (European Commission, 2006b). In addition in the UK reform to the cross compliance good agricultural and environmental condition (GAEC) standards is taking place to strengthen soils protection (Department for Environment Food and Rural Affairs (DEFRA) 2009), and a code of practice for the sustainable use of soils on construction sites has been developed (Department for Environment Food and Rural Affairs (DEFRA) 2008).

A number of EU member states have legislation that alludes to soil protection; however the majority of this is focused on soil contamination. A number of states do have policies addressing broader soil protection issues including Netherlands, Germany and Belgium. These states are some of the most advanced states for soil protection in EU, and found in a survey in 2003 to be the only states with a specific legally binding definition of soil (Van-Camp et al. 2003). The Netherlands have a number of policies to address long term protection, management and sustainable use of soils including the 1987 soil protection act (amended 2008) (VROM (The Netherlands Ministry of Housing, Physical Planning and the Environment) 1986), the 2003 Soil Policy Letter (van Geel 2003) and the 2009 soil remediation circular (VROM (The Netherlands Ministry of Housing, Physical Planning and the Environment) 2009). German policy for the protection of soils include the 1998 Federal Soil protection act (Federal Ministry for the 
Protection and Contaminated Sites Ordinance (Federal Ministry for the Environment Nature Conservation and Nuclear Safety 1999). There are a number of government agencies that have been established for soil protection, the Federal Institute for Geosciences and Natural Resources formally established in 1975 and the Federal Environment Agency Soil Protection Commission (KBU) in 2004. The Public Waste Agency of Flanders (OVAM) of the Flanders region of Belgium developed a soil remediation and protection decree in 2007, replacing a previous version of 1995 (Public Waste Agency of Flanders (OVAM) 2007). The Flemish government approved the 'Order of the Flemish Government establishing the Flemish regulation on soil remediation and soil protection' that accompanied the decree in December 2007 (Flemish Government 2007), replacing the previous version of 1995.

The soil framework directive proposes integration of soils into all policy making, prevention of degradation and pollution of soils, implementation of risk/priority areas and action programmes for erosion, compaction, loss of organic matter, salinisation, acidification and landslides, limitation and containment of soil sealing, and identification and remediation of contaminated sites (de Souza 2009). The proposed directive will require identification of risk areas on the basis of common elements, encouraging use of existing monitoring schemes with a move toward development of a harmonised monitoring approach (European Commission (EC) 2006c). There is general support for a Framework directive on soil protection, with the majority of states holding the view that the proposed directive will fill a gap in Union environmental legislation and provide a more holistic approach to soil protection (Council of the European Union 2010). Development of the soil framework has, however, been slow for a number of reasons including problems agreeing on an approach for identifying geographical "risk areas" or "priority areas" (ENDS Europe 2007). A knowledge based approach to soil monitoring aimed at delivering soil protection and sustainable use is introduced and required by the soil thematic strategy (Blum et al. 2004a; Blum et al. 2004b; Quevauviller and Olazabal 2003).

Despite the relatively recent introduction of policies for its protection, soil is an environmental medium that is often neglected, because there is not widespread understanding of the importance it has for ecosystems and the economy (Dimas and Gnacadja 2008). Despite the 
112 increase in environmental awareness, the same cannot be shown of the general society's 113 attitude toward soil $\{160$ Ferreira, M. da G. de V. X. 2006\}\}. The public's knowledge of, and 114 interest in other environmental media such as air and water are higher than of soils. For the 115 case of air, the level of knowledge is mainly because of the impact on public perception of the 116 history of air pollution and dramatic local events (Brimblecombe 2001). Similarly, water is 117 perceived as very important and has played its part in both historical and current conflicts 118 (Gleick 2008). The link between human health and both air and water quality has been a driver for developing public perception and the need for environmental regulations.

120 Even when conflicts have been associated with the availability of arable land and farm production, soil has never properly understood or perceived as important. On the contrary, soil

122 has often been pushed to the background in public commitment to environmental conservation.

123 This is in part due to the unaddressed problem of clearly defining soil, and the more 124 complicated issue of defining or assessing its quality. The links to the environment and human health are not evident for soil to the same extent as water and air. Soil is often taken for granted and often mistakenly confused with dirt. There is a need for defining and communicating a richer, more broadly nuanced, and positive societal value of soil and its quality. In an effort to protect soils through encouraging development of soil protection policy and legislation there is a need to clearly define soil and in order to assess the state of degradation to understand the term soil quality. This paper aimed to increase understanding of soil and soil quality through review of the definition of soil and developments in the definition of soil quality and its assessment. The paper summarises concerns that have emerged following a phase of development since the initial definition of soil quality in the 1970's. The historical review was undertaken to understand the difficulties in defining soil quality as well as problems and concerns with assessment of soil quality. The review incorporates major concerns and unease in the field of soil quality and developments in the field of environmental protection to refine the definition of soil quality. This work has suggested development of a complimentary method to inform and prioritise further detailed assessment of soil's quality. 
139 This review is particularly relevant due to the simultaneous development of a number of country

140 specific legislative instruments for soil protection and particularly with the emergence of

141 European legislative drivers. The work has relevance to the situation surrounding the proposed

142 framework directive on soil protection. As such the concepts presented in this work have

143 potential EU- wide application, with relevance at member state level but more importantly for

144 harmonisation across states.

\section{Soil and Soil Quality}

146 There is some variability in the definition of soil; a selection of definitions is presented in Table

147 1. An early legislative definition by the Netherlands Ministry of Housing, Physical Planning and

148 the Environment (VROM) is a simple statement about the physical nature of the soil; a definition

149 very similar to that of the Public Waste Agency of Flanders. The German Federal Ministry for

150 the Environment, Nature Conservation and Nuclear Safety definition is more detailed than that

151 of the Netherlands and Flanders, and includes not only the physical components of soil but

152 reference to soil's function. The Soil Science Society of America provides the definition that is

153 accepted by the US Department of Agriculture and this definition of soil demonstrates the

154 complex and multifaceted nature of soils (Soil Science Glossary Terms Committee 2008) The

155 definition as used by the Environment Agency of England and Wales (EA) introduces the idea

156 that soil is often seen as a resource, and therefore can be exploited (Environment Agency

157 2004). The definition in the proposed soil framework directive (in the proposal of the Czech

158 presidency) text is restricted to the chemical, physical and biological aspects of the soil, not

159 mentioning function or economic production.

Table 1 Definitions of soil in legislation and literature.

161 A lot of research has been undertaken to understand soil and describe its characteristics in

162 more general terms. For example, the chemical function of soil has been assessed on national, regional and local levels by use of geochemical mapping (Barraclough 2007; Johnson et al. 2005). The technique was developed in the 1950's to give information on the spatial distribution of chemical elements and compounds at the earth's surface (Johnson and Ander 2008). In 
general, there has been a great deal of work to investigate simplified functions and processes of soil science; these however are regularly limited to the specific sub discipline such as soil physics, soil biology or soil chemistry. There is a need to review the advances and development in the term soil quality, to define how the term relates to the uses of land and to anthropogenic activities.

171 The potential effects upon other media from the soil system have the ability to influence 172 compliance with regulatory standards such as the European Union Water Framework Directive which sets controls on the diffuse pollution from soil (European Commission (EC) 2006b). A method for prioritisation of impacts to groundwater from soils on a city wide scale is being developed by the British Geological Survey that takes into account factors including soil properties and soil metal concentration from urban soil survey data (Ó'Dochartaigh et al. 2009).

Despite the great deal of research into specific aspects of soil's quality, most of this work defines and assesses soil quality based on different simplified functions and processes of soil itself. An example of this is the agricultural land classification developed implemented in the UK to assess quality of agricultural land taking into account climate, site and soil characteristics and the interactions between them (Ministry of Agriculture, Fisheries and Food 1988). Another example is the great increase in research into, and investigation of, contaminated land since the 1970's. This was mainly a reaction to a number of high profile contamination incidents that attracted media attention, such as Love Canal and Times Beach in the USA, Lekkerkerk in the Netherlands, Minimata in Japan, and incidents in the UK such as the landfill gas explosion at Loscoe, redevelopment of a munitions factory in Enfield, the detection of hexachlorobutadiene in houses in Cheshire, and The Corby Litigation Group v Corby District Council case concerning reclamation of a former steel works in Corby (Nathanail and Bardos 2004; Williams and Aitkenhead 1991). The increase in contaminated land research is also due to an increase in development of Brownfield sites, inclusion of contaminated land as a consideration in the planning process, and a willingness of companies to identify environmental liabilities (Alker et al.

192 2000; Department for Environment Food and Rural Affairs (DEFRA) 2002; Harrison and Hester 193 2001). 
194 Contaminated land has the potential to pose serious environmental risks, including surface and

195 groundwater contamination, and risks to human health and safety (Balasubramaniam et al.

196 2007). Although likely to be covered in future holistic soil protection regimes contaminated land

197 is just one aspect of soil quality. It has traditionally had a separate legislative area with its own

198 related legislation and policy, independent from that of soil science and soil quality.

199 Environmental standards used to assess contaminated land should not be confused with

200 assessment of soil quality. The contaminated land legislative area includes not only legislation

201 specific to contaminated land but also general environmental, waste and resources, health

202 protection, and planning and building control. Exhaustive lists of contaminated land legislation

203 are available from state governments; however examples of the main acts relating to

204 contaminated land in a number of European states are detailed in Table 2.

205 Table 2 Examples of main contaminated land legislation in EU member states

206 There are some states with legislation specific to contaminated soil, and a number of states that

207 have overarching soil protection legislation; however these still focus to a large extent on soil

208 contamination. The legislative framework in EU member states has similarities in investigation

209 of presumed contamination; mostly following a similar stepwise approach with preliminary

210 investigation followed by detailed investigation and remediation (Provoost et al. 2006). Soil

211 cleanup standards are seen as a trigger for detailed investigation and remediation, however

212 these values vary in derivation and application across member states. For the case of soil

213 quality indicators, apart from contaminant concentration, trigger values for action have mostly

214 not been adequately researched and there is a lack of implementation so far within member

215 states (UK Soil Indicators Consortium 2006).

216 To support development of national contaminated land management programmes, a likely

217 requirement of the EU SFD (European Commission (EC) 2006c) a driver-pressure-state-impact-

218 response (D-P-S-I-R) framework has been suggested to provide an information framework to

219 support interventions on contaminated land management at a national level and the source-

220 pathway- receptor model to provide guidance at a site level (Rodrigues et al. 2009). This 
221 method would meet the requirement in the proposed SFD of identification of contaminated sites

222 but would not go so far as to meet the requirement to identify geographical risk or priority areas.

223 However, this identification will not be carried out by environmental policy itself and is likely to

224 require the development and use of additional tools.

225 Presence of contaminants from diffuse sources potentially present below traditional risk

226 screening levels should not be overlooked. Although through risk assessment the presence of

227 these contaminants is not necessarily considered a threat to human health, their presence can

228 impact upon other aspects of soil quality such as soil biodiversity (van Straalen and van Gestel

229 2008). Diffuse pollution of soils also has the potential to exacerbate the impact of other soil

230 quality aspects such as erosion, leaching and run off and ultimately upon a number of soil

231 functions (Quevauviller 2007).

232 Soil quality needs to include such contamination aspects, within a holistic assessment approach that includes other aspects of soil quality. As previously stated, soil degradation can be defined as a decline in soil quality, and major soil degradation processes are erosion, decline in organic matter, local and diffuse contamination, sealing, compaction, decline in biodiversity, salinisation, floods and landslides. Ultimately extreme degradation leads to desertification, an advanced stage of land degradation where the soil has lost part of its capability to support human communities and ecosystems (European Environment Agency (EEA) 1999). These soil degradation processes can, therefore, be seen as key threats to decline in soil quality and seen as a key focus of the definition, identification and assessment of soil quality.

Historical Review of Assessment of Soil Quality

242 Proposals to assess soil quality emerged initially in the USA. An early proponent of the concept 243 was Alexander (Alexander 1971) who first suggested developing soil quality criteria. The 244 development of the definition of soil quality over time is detailed in Table 3. 
The report "A framework for land evaluation" by the Food and Agriculture Organization (FAO) of

247 the United Nations defined land quality as "a complex attribute of land which acts in a distinct manner in its influence on the suitability of land for a specific kind of use" (Food and Agriculture Organisation (FAO) 1976). The FAO report introduced the idea that land quality is complex and should be assessed in relation to the specific function that the land serves Carter et al. (Carter et al. 1997) outlined the differences between land and soil quality whereby soil quality is more restrictive than land quality but frequently incorporates the same emphasis on use.

Warkentin and Fletcher (Warkentin and Fletcher 1977) developed soil quality as initially suggested by Alexander (Alexander 1971) by integrating the relationship of soil quality with the land function. The authors stated that assessment of soil quality was needed to facilitate better land use planning because of the increasing number of functions that soil resources must either provide or accommodate. Warkentin and Fletcher (Warkentin and Fletcher 1977) recognised the value of soils in the biosphere and stated that soils have not only current use value but also should have an intrinsic value. The relationship between soil quality and environmental quality is evident in the Anderson and Gregorich (Anderson and Gregorich 1984) definition. minimum data set of soil parameters which could be used to express the 'health' of a soil. The Larson and Pierce (Larson and Pierce 1991) definition introduces soil health, a term that can be used interchangeably with the term soil quality. The term soil quality, however, is one used more regularly by soil scientists and soil health used by other parties. The phrases, although used interchangeably, do however have different emphasis. Karlen et al. (Karlen et al. 1997b) state that soil quality can be viewed as an inherent characteristic of the soil, or as the condition or "health" of the soil. However, the difference in emphasis between soil health and soil condition was highlighted in Mausbach and Tugel (Mausbach and Tugel 1995) with soil health

270 differing from soil condition whereby soil health "is the ability of the soil to perform according to

271 its potential. Soil condition changes over time due to human use and management or to unusual natural events". 
273 Seybold et al. (Seybold et al. 1998) suggested that soil quality evokes various responses

274 depending on scientific and social background. To the land manager and farmer, soil quality is

275 often viewed as that of soil health (Romig 1995). Soil health is a term preferred by some as it

276 portrays soil as a living, dynamic system whose function is mediated by a diversity of living

277 organisms that require management and conservation (Doran and Zeiss 2000). Doran and

278 Zeiss (Doran and Zeiss 2000) state that the term soil quality is associated with a soil's fitness for

279 use and the term soil health is associated with the capacity of a soil to function as a vital living

280 system, to sustain biological productivity, promote environmental quality and maintain plant and

281 animal health.

282 Pierce and Lal (Pierce and Lal 1992) differentiated between the intrinsic properties of a soil as

283 determined by the soils development and degradation processes, and the soils productivity

284 describing the efficiency in use and management of resource inputs.

285 The classification of soil quality as "fitness for use" aligns soil quality assessment with soil

286 function (Pierce and Larson 1993). Assessment of soil quality requires the intended soil use to

287 be determined in order to establish the soils capacity to function (Schoenholtz et al. 2000).

288 Recent and proposed soil protection policy requires action on threats to soil with regard to the

289 soil function (Blum et al. 2004a; de Souza 2009). Carter et al. (Carter et al. 1997) suggested a

290 framework for evaluating soil quality that includes describing each soil function on which quality

291 is to be used, selecting soil characteristics of properties that influence the capacity of the soil to

292 provide each function, choosing indicators of characteristics that can be measured, and using

293 methods that provide accurate measurement of those indicators.

294 The Doran and Parkin (Doran and Parkin 1994) definition includes not only soils ability to

295 function, but includes key soil functions in the definition. A widely used definition of soil quality is

296 that of Karlen et al. (Karlen et al. 2001), the product of a Soil Science Society of America

297 (SSSA) Ad Hoc Committee on Soil Quality (S-581). The result of the committee on soil quality is

298 clearly based upon the Doran and Parkin (Doran and Parkin 1994) definition. The Karlen et al.

299 (Karlen et al. 1997a) definition is used widely by the United States Department of Agriculture 
300

301

302

303

304

305

306

307

308

309

310

311

312

313

314

315

316

317

318

319

320

321

322

323

324

325

326

including in their recent technical note (USDA- NRCS 2008). The definitions from both Doran and Parkin (Doran and Parkin 1994) and Karlen et al. (Karlen et al. 1997b) include dynamic soil quality, a term that refers to the condition of soil that is changeable in a short period of time by human impact including agricultural management practices (Idowu et al. 2008; Seybold et al. 1998).

Patzel et al. (Patzel et al. 2000) attempted to make a distinction between soil fertility and soil quality for the German language literature. The distinction of soil quality from soil fertility was recommended to prevent ideal attributes in soils being included in the definition of soil fertility and to reduce confusion associated with the two terms as has been seen in the USA.

In the USA the establishment, in 1993, of a Soil Quality Institute (SQI) provided the United States Department of Agriculture (USDA) Natural Resources Conservation Service (NRCS) with an emphasis on soil quality. The SQI has a mission to develop and disseminate tools for soil quality assessment (Ditzler and Tugel 2002).

In summary soil quality has developed from the suggestion by Alexander (Alexander 1971) that soil quality criteria should be developed, later in the 1970's it was suggested that soil quality should be evaluated in relation to land function (Warkentin and Fletcher 1977). The interaction with holistic environmental quality, water and air quality was discussed in the mid 1980's (Anderson and Gregorich 1984). There was much discussion of the subject in the 1990's including suggestion of minimum data sets for assessment, discussion about the differences between soil health and soil quality, and a differentiation between the intrinsic properties of a soil and soils productivity as a result of management practices (Doran and Zeiss 2000; Karlen et al. 1997b; Larson and Pierce 1991; Mausbach and Tugel 1995; Pierce and Lal 1992; Romig 1995; Seybold et al. 1998). Doran and Parkin (Doran and Parkin 1994) and Pierce and Larson (Pierce and Larson 1993) developed the definition further by including key soil functions, the fitness for use and the dynamic state of soils in the definition of soil quality, which clearly inspired later definitions (Karlen et al. 1997b; USDA- NRCS 2008), and soil protection policy (Blum et al. 2004a; de Souza 2009). 
328 Despite formation of a soil quality institute in the USA and a large amount of discussion

329 predominantly attempting to define soil quality, consensus amongst the scientific community on 330 a precise definition of soil quality has not been reached (Ditzler and Tugel 2002). This is likely to 331 be due to the innate difficulty in the definition of soil and the complex nature (i.e., scientific, 332 personal, and social) of environmental concerns (Carter 2002).

333 Following the large amount of work to define soil quality, there has more recently been some 334 dispute about the relevance and impact of soil quality. MacEwan and Carter (MacEwan and 335 Carter 1996) and Carter (Carter 2002) stated that although soil quality describes an objective 336 state or condition of the soil, it also is subjective, evaluated partly on the basis of personal and social determinations. Doran and Parkin (Doran and Parkin 1996) described that in the 5 years preceding the publication there had been concern about deficiencies in the basic understanding of soil quality and a lack of a mechanistically based soil quality methodology, particularly of the soil biota.

Sojka and Upchurch (Sojka and Upchurch 1999) expressed concern over the move in soil science from value neutral tradition of edaphology, and specific problem solving to paradigm based on variable and often subjective societal perceptions of environmental holism. Sojka and Upchurch (Sojka and Upchurch 1999) suggested that although soil quality does acknowledge the variable soil functions it fails to integrate simultaneous, diverse and often conflicting soil functions and emphasises the importance of understanding rather than rating of the soil resource. Conflicts occurring for example between agricultural production or use as a platform for construction and functioning as an environmental buffer and store of water.

Concerns expressed by Karlen et al. (Karlen et al. 2001) emphasise the lack of inclusion of soil functions and meaningful indicators for those functions. Karlen et al. (Karlen et al. 2001) discussed the difficulty in interpreting indicators for various soil functions that can be used to track soil quality over time. Letey et al. (Letey et al. 2003) expressed that soil quality has a dysfunctional definition, that there are problems in the approach to quantification of soil quality. 
354

355

356

357

358

359

360

361

362

363

364

365

366

367

368

369

370

371

372

373

374

375

376

377

378

Letey et al. (Letey et al. 2003) agreed with Sojka and Upchurch (Sojka and Upchurch 1999)who stated there is a failure of soil quality to integrate simultaneous soil functions which often require contradictory soil properties and management, for example high levels of mineralisable nitrogen/ low levels of nitrate nitrogen and levels of available nitrogen to crops (Karlen et al. 1997b).

Sojka et al. (Sojka et al. 2003) expresses many of the concerns in earlier literature including those about the elusiveness and value-laden nature of the soil quality definition. The work reiterates concerns expressed by earlier studies into the often multiple functions of soils that occur simultaneously and that development of soil quality assessment has diverted research and management away from developing improved management to solve problems.

There have been issues defining the boundaries of assessment when evaluating soil quality. Rather than focusing on ability to carry out specific functions increasingly issues such as the environmental cost of agricultural production and the potential for reclamation of degraded soils is considered when discussing soil quality (Singer and Ewing 2000).

\section{Soil Functions}

As described by critics of soil quality, soil can have multiple functions. Sojka and Upchurch (Sojka and Upchurch 1999) describe how soil performs several functions simultaneously not several functions separately. Letey et al. (Letey et al. 2003) described how soil may perform well for one function and badly for another function that is occurring simultaneously. Letey et al. (Letey et al. 2003) describes how Karlen (Karlen et al. 1997a) acknowledged problems with assessing soils multiple functions when reviewing Doran and Werner (Doran and Werner 1990) where the soil management was affecting the rating and performance of two functions.

There is considerable overlap in the functions of soil as expressed in the literature, though expressed in different wording the soil functions expressed by different sources cover the same areas: 
- Maintains biological activity and productivity (Doran and Parkin 1994; Karlen et al. 1997b), serves as a medium for plant/food/fibre growth (European Commission (EC) 2006b; Larson and Pierce 1991; Loveland and Thompson 2002), supports plant productivity/yield (Karlen et al. 1997b), supports human/animal health (Doran and Parkin 1994; Karlen et al. 1997b);

- Acts as a biodiversity and gene pool (European Commission (EC) 2006b; Lal 1997; Lal 1998; Montanarella 2008)

- partitions and regulates water/solute flow through the environment (Karlen et al. 1997a; Larson and Pierce 1991);

- serves as an environmental buffer or filter (European Commission (EC) 2006b; Larson and Pierce 1991; Loveland and Thompson 2002), maintains environmental quality (Doran and Parkin 1994; Karlen et al. 1997a)(Karlen et al. 1997a)\{\{181 Karlen, D.L. 1997\}\}(Karlen et al. 1997a);

- cycles nutrients, water, energy and other elements through the biosphere (Karlen et al. 1997a);

- supports socioeconomic structure, cultural and aesthetic values, (Lal 1998) and a platform for human activities and landscape (European Commission (EC) 2006b; Sombroek and Sims 1995)(Sombroek and Sims 1995)\{\{231 Sombroek, W.G. 1995\}\}(Sombroek and Sims 1995);

- an archive of heritage (European Commission (EC) 2006b; Lal 1998; Sombroek and Sims 1995).

Lal (Lal 2007) reviewed the scientific literature and classified soil function research into the themes of food security, bio fuels production, waste disposal, carbon, farming, and water resources.

The soil functions that have been suggested in the literature generally fit in with the definition of ecosystem services, the benefits that human beings gain from natural ecosystems as defined by Daily (Daily 2000). Ecosystem services can be categorised as the production of goods, 

options (Daily 2000).

408

409

410

411

Soil quality has connections to other environmental mediums, and the biological systems that are supported by the soil. The interconnections can be described as direct or indirect, as detailed in Figure 1.

Figure 1 Connections between soil health and the environmental and biological systems supported by soil. Direct (1a-1d) and Indirect (2a-4a) quality and health connections of soil to air, water, plants, animals, and people (after, Harris et al., 1996).

The ecological risk assessment process (also referred to as environmental risk assessment) evaluates the potential significance of impacts in regard to likely effects upon ecological receptors as the result of exposure to a stressor (Hope 2006; Suter 2007). Ecological risk assessment includes evaluation of ecological aspects for each soil use to formulate soil screening values based upon soil use (European Chemicals Bureau 2002; Quercia et al. 2002).

Toxicity of contaminated soils has become a major focus in ecological risk assessment, and can be used to set generic or site-specific soil quality guidelines and for guiding on-site contamination mapping and remediation (Burns et al. 1996; Suter 2000). Toxicity data informing ecological risk assessment can be comprised of single-chemical or single material data; ambient media toxicity, site-specific insitu or laboratory toxicity tests of contaminated media; or biological survey, site specific sampling or observations of organisms, populations or communities in contaminated areas(Suter 2000). Increasingly use of single bioassays have been found not to provide a full enough picture of the quality of the environment, therefore battery tests of a number of bioassays of different animal and plant species from different trophic levels have been used to reduce uncertainty(Bierkens et al. 1998; Juvonen et al. 2000). Although bioassays have been used extensively in assessing the effects of contaminants in soil, use in assessment of other aspects of soil quality have been limited (Schloter et al. 2003; Seybold et al. 1998). It has been suggested that bio assays should not be used as the only measure of soil quality. The response of a bioasay is a function of many confounding non-soil factors in addition to soil quality. Soil sustainability and the effects of management should be 
determined by measuring soil properties and processes directly (Burger 1996; Seybold et al. 1998).

\section{Soil Quality Indicators}

Soils have chemical, biological and physical properties that interact in a complex way to give soil its capacity to function (Seybold et al. 1998). Owing to the wide scope of functions encompassed in the definition of soil quality, it is not possible to directly assess soil quality (Burger and Kelting 1999; Ditzler and Tugel 2002; Doran and Parkin 1994). Existing methods have first identified the functions of interest and selected indicators to observe and measure, inferring the ability of the soil to perform that function (Ditzler and Tugel 2002). The use of indicators of soil quality has been discussed widely in the literature and minimum data sets suggested in a number of studies (Arshad and Cohen 1992; Bouma 1989; Doran and Parkin 1994; Larson and Pierce 1991).

Common to the minimum data sets of soil quality indicators suggested in the literature is that they include a combination of physical, chemical and biological soil properties. This suggests that for a soil to function effectively all three factors must be addressed, as illustrated in Figure 2 (Ditzler and Tugel 2002; Stenberg 1998). These classes of properties match the physical, chemical and biological soil degradative processes, mechanisms that set in motion the degradative trends (Lal 1997). Typically soil assessment has looked at chemical properties, measured using chemical indicators, or has looked at properties and indicators specific only to the function of interest. Holistic soil quality attempts to integrate the three types of soil properties (Karlen et al. 2003). There is rarely an exact match between function and indicator, with a function often supported by a number of soil properties and a soil property or process being relevant to several soil attributes or functions simultaneously (Schoenholtz et al. 2000). Correspondingly categories of soil properties (chemical, biological, physical) do not exactly align with the soil functions. The complex interactions between soil properties, indicators, and soil functions require that for assessment of soil quality integration of soil properties into the soil property categories is necessary. 

following features:

- $\quad$ possess an available baseline against which to compare change;

- $\quad$ provide a sensitive and timely measure of a soil's ability to function;

- be applicable over large areas but specific enough to be sensitive;

- be capable of providing a continuous assessment;

- be inexpensive, easy to use, collect, and calculate;

- discriminate between natural changes and those induced by management;

- be highly correlated to long-term response; and

- be responsive to corrective measures.

473 The increase in the value of basic data by using it to estimate more expensive and laborious to 474 obtain data were named by Bouma (Bouma 1989) as pedotransfer functions (PTFs) and defined 475 as translating data we have into what we need. Computer programs such as Soilpar (Acutis and 476 Donatelli 2003) and Rosetta (Schaap et al. 2001) were developed to estimate the soil hydraulic properties from surrogate soil data such as soil texture, bulk density, organic carbon, soil pH, and cation exchange capacity. Pedotransfer functions were the basis for the development of soil interference systems (SINFERS) that take measurements known with a level of certainty and infer data that is not known with minimal inaccuracy using logically linked predictive functions (pedotransfer functions) (McBratney et al. 2002).

\section{Risk Based Approach to Soil Quality}

Regulatory bodies are increasingly using risk based approaches to environmental decision making (Pollard et al. 2002). Such risk based decision making does, to some extent, include soil quality, however this is predominantly in the assessment and management of soil contamination, just one part of soil quality. Although use of risk based methods have not been extensively used to assess other aspects of soil quality, the methods and decision making processes have potential for wider application in soil quality assessment. 
In such current soil contamination risk based assessment the effect of contaminants on humans

490

491

492

493

494

495

496

497

498

499

500

501

502

503

504

505

506

507

508

509

510

511

512

513

514 and ecosystems is investigated, rather than using the total contaminant concentration in the soil (Madejón et al. 2006). The source- pathway- receptor pollutant linkage is used in environmental risk assessment and used extensively in the assessment of risks from contaminated land (Nathanail and Bardos 2004). In assessment of risk from contaminated land a potential for risk exists if there is a source of contaminants, a receptor sensitive to the contaminant at the level of exposure present, and a pathway linking the two. A potential risk is said to exist, only if all three (source, pathway and receptor) elements are present (Hardisty and Özdemiroğlu 2005).

Definition of a soil's quality in terms of the source- pathway- receptor linkage allows potential for assessment in terms of the risk posed to or from soil to other environmental mediums, and allows the inclusion of soils often multiple functions. Although a function of soil is to act as an environmental filter (European Commission (EC) 2006b; Larson and Pierce 1991; Loveland and Thompson 2002) soil has the ability to act as a source, a pathway and a receptor to contaminants. All three aspects being affected by indicators of properties regularly used to determine soil quality, the linkage, processes and properties are detailed in table 4 .

\section{Table 4 Interaction between risk linkage, soil process, and soil properties}

A contaminant is a substance that is not naturally present in the environment or is present in concentrations with the potential to adversely alter an environment (Saunier and Meganck 2009). Soil can act as a primary source of contamination, that is a direct flux, or a secondary source by the release of contaminants that have previously affected the soil. The potential of soil to act as a source is highly variable due to the heterogeneous nature of the soil both with regard to controlling soil properties but also the chemicals present and their concentration. The nature of soils being dynamic means that there is a flux of chemicals across soil depths (i.e. movement from topsoil to sub soil and the opposite) and spatially. There are constant changes in the soil state due to natural leaching processes and interactions/ fluxes between soil water, soil gas and the organic and mineral components of soil. 
515 Soils functioning as a source can occur when water travels through the soil matrix, combined

516 with carbon dioxide to form a weak carbonic acid, acting as a pathway. As the weak carbonic

517 acid moves through soil, small amounts of naturally occurring minerals and man-made

518 chemicals held within the soil matrix are dissolved and held in solution, a process known as

519 leaching (Neung-Hwan and Richter 2004). Potential receptors can include ground and surface

520 waters, drinking water, humans, animals, services, industrial processes, and household

521 appliances. Calcium and magnesium leached from the soil is a cause of "hard water" making

522 soaps and detergents less effective and effecting water-using appliances (Boyd 2000). In small

523 doses fluoride, iron, and copper can be beneficial to human health but in larger doses can be

524 harmful (Bogden and Klevay 2000). Elements such as lead, arsenic, and mercury are of

525 concern to human health (Alloway 1994). Although carbonic acid is the main leaching agent in

526 natural systems leaching is dependent on the type, quantity and characteristics of the leaching

527 agent; there are many natural and anthropogenic lixiviation agents including sulphuric acid, and

528 humic or fulvic acids (Johnson et al. 1979). Alternative leaching agents have been researched

529 extensively in the remediation of contaminated soils (Dirilgen et al. 2010; Johnson et al. 1979).

530 Common soil properties that determine the rate and quantity that material is leached from soils

531 include the cation exchange capacity (C.E.C.), crop/ plant cover, soil texture, soil permeability,

532 soil organic matter, soil $\mathrm{pH}$. Leaching is also dependent on climatic factors such as temperature

533 and precipitation. Due to the number of controlling factors and the large variability in these

534 properties soils have a resultant highly variable susceptibility to leaching,

535 In addition, soil can act as a source of contaminants through pathways such as the ingestion of

536 plant or animal products that have assimilated contaminants from the soil, with humans or

537 animal health as receptors (Collins et al. 2006; Earl and Kearney 2000; Michaud et al. 1991;

538 Sjöström et al. 2008). Soil properties which affect the bioavailability of contaminants include soil

$539 \mathrm{pH}$, soil texture, soil C.E.C., soil organic matter, porosity, bulk density, water content, hydraulic

540 conductivity, and soil temperature (Chiou et al. 2001; Hung and Mackay 1997; Massas et al.

541 2002; Ryan et al. 1988; Topp et al. 1986; Trapp and Matthies 1995; Travis and Arms 1988).

542 Plants can modify the rhizophere by production of organic acids and therefore may exclude or

543 accumulate contaminants selectively (Glick 2004). 
544 There is also potential for the ingestion of contaminated soil directly by humans (especially

545 children) and animals (Beyer and Connor, E. E. Gerould, S. 1994; Calabrese et al. 1997). In this

546 case the soil would be a source and a pathway to the receptor. In this case a physiologically

547 based extraction test (PBET) can relate bioavailability to soil properties such as pH, C.E.C., Fe-

548 and Mn-oxide content, particle size distribution, and total organic and inorganic $\mathrm{C}$, water

549 content, bulk density, porosity (Stewart et al. 2003a; Stewart et al. 2003b; Thompson et al.

550 1992). The atmosphere can act as a pathway of contaminants from a soil source where there is

551 a vapour transfer of contaminants to a receptor of humans, animals or buildings (Cowherd et al.

552 1985; Jury et al. 1990; Little et al. 1992). Soil vapour transfer is influenced by climatic and

553 meteorological factors as well as soil properties of total porosity unsaturated zone, water filled

554 porosity unsaturated zone, organic carbon fraction, soil dry bulk density, soil permeability,

555 moisture content, soil texture as well as soil temperature (Evans et al. 2001; Fischer et al.

556 1996). Besides vapour transfer of contaminants other soil to atmosphere transfers exist such as

557 radon. Radon-222 is a natural radioactive gas that is produced from the decay of radium

$558\left({ }^{226} \mathrm{Ra}\right)$, itself produced from the decay of uranium, found naturally in small, but hererogenous,

559 quantities in all soils and rock (Appleton 2007). Exposure to radon indoors is the largest

560 contributor to radiation exposure and has been linked to lung cancer (Darby et al. 1998; Miles

561 and Appleton 2005). Soil gas has been identified as the main source of indoor radon (Nazaroff

562 and Sextro 1989). Radon potential is the result of a combination of the properties of the soil,

563 and the underlying geology such as the radium concentration and its distribution in the soil, the

564 soil porosity, permeability, moisture content and also meteorological variables (Winkler et al.

565 2001).

566 Soil, as mentioned above, has the potential to act as a pathway. An example of this is the 567 creation of soil particulate matter by the process of wind erosion (Cave et al. 2009; Macleod et

568 al. 2006). The particulate matter can carry contaminants to receptors such as humans or other

569 organisms. Soil properties affecting wind erosion include soil erodible fraction, soil crust, soil

570 roughness, soil texture, and bulk density, plant factors that can affect wind erosion include

571 growing crops and flat and standing residues in addition to climatic factors (Fryrear et al. 1998;

572 Fryrear et al. 2000). Another example is the soil migration, plant uptake and volatilisation of 
573 radio-selenium material through from contaminated groundwater, dependent on the soil redox

574 status (Ashworth and Shaw 2006).

575 Soils can also be a receptor, especially when they are perceived as a product, or a media that 576 needs to be protected from pollution. Sources of soil contamination are diverse and can be 577 defined as point source or non point source (Rawlins et al. 2005). Point sources are those 578 where the source of pollution is clearly identifiable and can be traced back to the specific source 579 such as leakages from underground storage tanks (Naidu et al. 2006a). Point source pollution is 580 typically associated with acute pollution incidents and the assessment of this falls under the 581 remit of traditional contaminated land investigation. With an increase in environmental 582 legislation and environmental awareness since the 1970s and 1980s point source pollution has 583 come under increasingly strict control. There has consequently been an increasing emphasis on 584 non point source pollution. The historic definition of soil quality has related to non-point or 585 diffuse pollution and its effects on the ability of soil to function. The effects of anthropogenic 586 contamination can be assessed through monitoring of soil quality indicators over time. Non 587 point source pollution of soils is where there is no obvious single point source of discharge and 588 the contamination is widespread in nature (Naidu et al. 2006b). This type of contamination, 589 when compared to point source contamination, can typically be described as chronic pollution 590 and can be associated with a decline in soil quality. Non point contamination sources that have 591 the potential to effect upon soils ability to function can include aerial transport and deposition of 592 contaminants from a number of anthropogenic activities such as transport and heavy industry 593 (Facchinelli et al. 2001) fertiliser and pesticide application (Mostaghimi et al. 2001; Torbert et al. 594 2002), and use of soil amendments (Voulvoulis and Lester 2006). The susceptibility of soils to 595 act as a receptor to contaminants depends not only on the presence of point or diffuse sources 596 of pollution and the concentration of contaminants but on a number of soil properties and other 597 factors. Susceptibility of soils to act as a receptor can be defined as the potential of soils to be 598 effected by contaminants, this either by limiting build up of contaminants, by buffering 599 contaminants, or degrading them (Glazovskaya 1990; Karlen et al. 2001). 
601 The range of definitions of soil quality has developed since its initial inception by Alexander

602 (Alexander 1971), notably by the inclusion of consideration of the soil function. Since the initial 603 activity however, development has slowed and there have been a number of challenges to the 604 definition of soil quality. Recent concerns are due to the failure of soil quality assessment to 605 integrate simultaneous soil functions which often require contradictory soil properties and 606 management (Letey et al. 2003; Sojka and Upchurch 1999; Sojka et al. 2003).

607 Soil quality should not be defined solely by the ability of soils to perform a single function (Sojka 608 and Upchurch 1999). It should include the potential to perform the multiple functions that are 609 desired of it, by humans, ecosystems and to be able to successfully provide ecosystem 610 services. It should also encompass that the soil can act as a source or pathway to other 611 environmental media or soil functions.

612 Such a multiple functional soil quality definition takes into account the growing need for 613 assessment of soil quality to incorporate the multiple and possibly conflicting functions of soils 614 (Letey et al. 2003). Therefore soil quality assessment should be improved to meet changes in 615 attitudes to soil and the environment being more than just a resource.

616 Soil quality assessment, taking into account the multiple functions that soil provides, normally 617 utilises a selection of indicators specific to the soil functions of interest (Ditzler and Tugel 2002).

618 To that extent, dynamic indicator systems, whether selected using expert opinion or other 619 methods such as principal component analysis, can create a good data set for assessment of 620 soil quality. However even then, such methods cannot effectively compare soil quality between 621 different soils of different functions. In addition, they often require indicators which are 622 expensive and difficult or laborious to collect data for. Although there may be conflicting 623 functions that soil is required to carry out, there is a notion that this does not happen in many 624 circumstances and that simultaneity of soils functions can take place. While soils function may 625 determine ideal values for soil properties, there is overlap between the soil properties necessary 626 for the assessment of the ability to carry out a specific function and these properties can be 627 included in a minimum dataset. 
628 Following a risk based approach such methods could be used initially to rank sites according to 629 a specified soil function, but could not allow for the identification and prioritisation of areas for 630 further investigation required for cross functional improvements. To improve such a screening 631 step, cross functional indicators could be developed to enable ranking and prioritisation across 632 different soil functions to inform further detailed investigation and risk assessment. The use of 633 soil indicators in soil protection and soil quality assessment in legal frameworks is currently 634 limited across Europe. The European environment agency has mapped soil quality of some southern European states, using indices based on soil parent material, soil depth, soil texture and the slope of the land surface. The indicator system appears to focus on desertification, 637 where the soil has lost part of its capability to support human communities and ecosystems 638 (European Environment Agency 2009). The UK Environment Agency undertook research into soil quality indicators, and suggested using total above-ground biomass production, total below-

640 ground soil organic carbon, topsoil pH, buffering capacity, keystone species, soil microbial 641 diversity, soil surface condition, extent and depth of ploughing, area of land taken for mineral 642 workings (Loveland and Thompson 2002; Merrington et al. 2006). In a review of this work in 6432006 , the minimum data set was revised to soil organic carbon, total nitrogen, Olsen P, 644 available and total copper $(\mathrm{Cu})$, nickel $(\mathrm{Ni})$ and zinc $(\mathrm{Zn})$, bulk density, and $\mathrm{pH}$. This minimum dataset has a bias toward soils chemical factors.

646 The cross functional indicators should collect information on soils chemical, physical and 647 biological properties and the associated factors that determine soils quality. Specific indicators 648 used would depend on the method of data collection, sampling strategy, available resources, 649 desired decision making output, and scale of application. Assessment must take place if a 650 desired level of data quality will be met for indicators selected to allow adequate evaluation of 651 the soil quality. However independent of factors controlling the amount of information collected 652 there is a minimum dataset that will be required for assessment of soil quality. The minimum 653 dataset is likely to include $\mathrm{pH}$, soil texture, organic carbon, infiltration rate, root presence, plant 654 cover, soil odour, soil organism presence and diversity, soil colour, evidence of anthropogenic 655 disruption (i.e. presence of construction material, coal/ soot) and penetrability. In addition 656 important information about landuse and habitat will provide useful information. This information 
657 will likely provide more useful information when investigated spatially and not necessarily at a 658 site specific level. The scale at which these indicators would be applied depends on the spatial 659 variation of soil properties, and research into this should be undertaken in the design stage of 660 the system. Such method should be built upon significant experience of the use of screening 661 tools in environmental and other applications.

662 Detailed environmental assessment is often informed by the use of screening tools. Screening 663 tools are generally designed to gather a large amount of information quickly and at a low cost. 664 Screening tools are used extensively in many areas including healthcare, product development, 665 international development, and environmental quality (Calantone et al. 1999; Department for 666 International Development (DFID) 2003; Elmore et al. 2005). Screening tools used in the 667 environment include flood risk (Department of Communities and Local Government (DCLG) 668 2006), site prioritisation and regulation (Environment Agency 2009), contaminated land 669 (Environmental Protection Agency 1996; Pollard et al. 2004), air quality (Department of the 670 Environment (DoE) 1997), water quality (Alvarez-Guerra et al. 2009), environmental fate 671 (Duarte-Davidson and Jones 1996; Wilson et al. 1996)and chemical risk (Pan et al. 2009).

672 Similarly, the development of a ranking and prioritisation method for soil quality assessment has 673 the potential to help toward implementing current and future soil regulation, for example the soil 674 thematic strategy (European Commission (EC) 2006b) and the likely requirements of the SFD 675 (European Commission (EC) 2006c; Van-Camp et al. 2004). The development of cross 676 functional soil indicators could facilitate direct comparison of soils and as such allow 677 prioritisation of soils flagged for further attention. Such indicators should be standard for every 678 soil assessed, allowing expert knowledge of the methodologies by personnel carrying out 679 multiple assessments with a resulting decreased level of error. The output of such assessment 680 should still provide all the information incorporated and not just be a single index figure of soil 681 quality. It should aim to provide evidence collated into a number of indices; that could be used 682 by specialists to inform further decision making.

683 The selection of cross functional soil indicators, development of their indices and methods for 684 interpreting them are all very challenging tasks. The use of Pedotransfer functions as predictive 
685

686

687

688

689

690

691

692

693

694

695

696

697

698

699

700

701

702

703

704

705

706

707

708

709

710

711

712

functions of certain soil properties when determining soil quality indicators could support efficient assessment of soil quality (Bouma 1989; Jana et al. 2007). For example, soil name, topsoil textural class, land use, and mean temperature are often used to facilitate the estimation of the topsoil organic carbon (Daroussin and King 1999). A compiled cross functional soil indicator dataset could also be complemented by data from other sources to make estimates of other soil properties. Use of soil inference systems can be used to make estimates of expensive, difficult to obtain or unavailable indicators from the less expensive and easier to obtain broad soil indicators (McBratney et al. 2002).

In addition, previous soil quality assessment methodologies have not assessed soil organisms in the same detail as soil physical and chemical properties. The presence and types of soil organisms can facilitate cross functional screening indicators and their use has great potential in soil quality assessment and remediation (Héry et al. 2008; Singer et al. 2001). Such as approach is in accordance with other environmental quality assessments that incorporate ecological risk in their frameworks (Ashton et al. 2008).

The system of prioritisation of soils using measurement of cross functional indicators suggested in this paper does not aim to replace current methodologies that are required for risk assessment. It is not an alternative to the Triad approach that requires the simultaneous and integrated deployment of chemical, toxicological and ecological lines of evidence for risk assessment (Chapman 1986; Rutgers et al. 2001). On the contrary, the results of this screening step aim to support the weight of evidence approach (Burton et al. 2002; Chapman et al. 2002; Interdepartmental Group on Health Risks from Chemicals 2002) by identifying areas of concern, focusing risk assessment investigations to reach a conclusion about an environmental system or stressor.

Such a screening option has also the potential to facilitate long term soil quality monitoring programmes. Although soil surveys have been carried out, these generally are not repeated in time and therefore qualify as inventories rather than monitoring programs (Department for Food and Rural Affairs (DEFRA). 2003). Monitoring programs currently generally rely on repeat visits to a number of preselected sites e.g. Countryside Survey (Carey et al. 2008) and the 
714 and inventory programs, especially those carried out before 1990, have largely omitted urban

715 soils due to the emphasis of the programs use on mineral extraction, wanting to exclude

716 anthropogenic pollution (Johnson and Ander 2008). There are also issues with difficulty of

717 accessing sites, and the heterogeneity of the urban environment. A prioritisation method that

718 repeats surveys over time has the potential to be used to monitor soils and to provide data for

719 areas where lacking from other programs, however will not replace existing monitoring

720 programs. Such methods have the potential to fill in gaps in existing monitoring regimes and

721 inform the need for further function specific assessment, potentially providing useful information

722 to meet current and future regulations relating to soil and their protection. Methodologies to

723 assess the impacts of land management practices and pollution on soil need to be developed,

724 with this leading to practices preventing and managing degradation of soils. Broad cross

725 functional indicators might be more appropriate for such use.

726 Soils do not have a static state and properties can vary significantly both spatially over small

727 distances, and over time. Due to the dynamic state of the system a single measurement in

728 space or time can be problematic in evaluation. There is a need to assess the dynamics of soil

729 quality associated with varying soil properties and intrinsic cycles and trends associated with the

730 spatial and temporal variability of soil properties and soil quality, which can be evaluated using

731 methods such as control charts (Larson and Peirce 1994). There is a need to relate clearly how

732 the dynamic state of soils influences its ability to function, and ultimately the soil quality. Use of

733 suggested cross functional soil quality indicators could allow repeat measurements can be

734 affordably collected. Collection of repeat indicator measurements can allow determination of

735 how spatial and temporal variability of soil properties can influence soil quality. It is with this

736 knowledge that it can be adequately determined if soil quality is changing due to natural

737 variation or is in fact subject to decline.

738 Screening methodologies could be developed with the potential to act as the basis for collection

739 of soil characteristics by non specialists, allowing for even more cost effective, relatively quick,

740 easy screening of soil characteristics. Use of a larger group of personnel makes regular 
741 repeated measurements of soils more feasible than solely using experts; however it would

742 require considerable organisation and commitment from participants to provide more than just

743 one off data. This could however be accomplished using keen specialist groups.

744 In general, based on the review undertaken in this work, further research is required to develop

745 an effective methodology/ framework for soil quality assessment under emerging regulatory

746 requirements. As discussed, research is needed to better establish the spatial and temporal

747 variation in soil properties this allowing the scale of application of soil quality assessment

748 methods to be determined. There is a clear need to establish the relationship between soil

749 organisms, soil properties and soil quality; this has the potential benefit of identifying organisms/

750 species that can be used as holistic bioindicators of soil quality or of more specific threats for

751 example soil contamination. There is an ongoing need to establish linkages between soil

752 indicators, effectively allowing further development of pedotransfer functions allowing the most

753 resource efficient establishment of soil properties. Development of a method for assessment of

754 the collected information needs to build upon the significant application of environmental risk

755 assessment and screening decision making; research will need to draw upon expert knowledge

756 of the soil system and interactions between the biological, chemical and physical factors.

757 Methodology development will need considerable calibration with existing datasets and field

758 testing in a range of situations from severely degraded sites to those considered pristine.

759 As well as soil regulation, screening and prioritisation of sites could have the ability to fit well

760 with the modern needs of environmental protection and policy, complimenting the recent move

761 to a holistic approach to environmental appraisal.

\section{Conclusion}

763 There are a number of new and emerging regulations which aim to protect soils and prevent soil

764 degradation. Soil degradation is often seen as closely related to, and effecting, soil quality. In

765 order to protect soils from a decline in soil quality and ultimately from soil degradation it was

766 necessary to improve the understanding of the terms soil and soil quality and to review how soil

767 quality is assessed. 
This paper has reflected that assessment of soil quality that has integrated soils function has not achieved consensus in the scientific community. Assessment of soil quality with respect to

770 its function can rely on expensive and time consuming methods. The use of different indicators chosen dependent on the soil function is potentially challenging with regard to comparison of quality between soils with different functions. A method to evaluate and prioritise further investigation and risk assessment could be developed that uses cross functional indicators.

774 Use of cross functional indicators could prove a more effective method to assess soils ability to meet the multiple and often conflicting requirements of it. The use of indicators in this way should significantly contribute to the knowledge based approach to soil monitoring and inform soil protection and sustainable use.

A standardised methodology for the assessment and comparison of many soils with different and multiple soil functions requires the development of set of a broad soil indicators. Indicators that are selected for inclusion in a site identification and prioritisation method should be crossfunctional, that is applicable to many soil functions. Soil quality indicators currently in use in existing soil quality assessment tools and monitoring programmes should be assessed for their ability to act as cross-functional indicators and inclusion in Pedotransfer functions.

The use of screening methods using broad soil indicators that do not rely upon specific soil functions has the ability to fit well with the modern needs of monitoring within soil regulation, as well as general environmental protection and policy. It has the potential to provide information to assist in compliance with legislation requiring monitoring or identification of geographical risk/priority areas such as the proposed EU Soil Framework Directive and the EU Soil Thematic Strategy. Such methods could highlight areas requiring further attention and threat dependent assessment for example detailed identification of areas requiring special protection from erosion, organic matter decline, compaction, salinisation, landslides, and acidification, using indicators specific to the threat in question. There have been problems reaching agreement on the content of the proposed Soil Framework Directive partly because of the different methods used in European member states and the requirement to identify risk/priority areas requiring special protection from erosion, organic matter decline, compaction, salinisation, landslides and 
796 acidification. A systematic approach to identification of areas of concern could help with this 797 requirement and allow progress to be made on development of the directive. 
799 The authors wish to acknowledge the Engineering and Physical Sciences Research Council

800 (EPSRC) for a PhD studentship and the Big Lottery Fund for facilitating collaboration between

801 Imperial College London, the Environment Agency, British Geological Survey and ERM. 


\begin{tabular}{|c|c|c|}
\hline Soil Definition & Jurisdiction & Reference \\
\hline $\begin{array}{l}\text { The upper layer of the earth's crust, as far as this } \\
\text { layer fulfils the soil functions, and including its liquid } \\
\text { components (soil solution) and gaseous components } \\
\text { (soil air), except groundwater and beds of bodies of } \\
\text { water }\end{array}$ & Germany & $\begin{array}{l}\text { Federal Ministry for the } \\
\text { Environment Nature } \\
\text { Conservation and Nuclear } \\
\text { Safety } 1998\end{array}$ \\
\hline $\begin{array}{l}\text { The solid part of the earth including liquid and } \\
\text { gaseous compounds and organisms therein }\end{array}$ & Netherlands & $\begin{array}{l}\text { VROM (The Netherlands } \\
\text { Ministry of Housing, } \\
\text { Physical Planning and the } \\
\text { Environment) } 1986\end{array}$ \\
\hline $\begin{array}{l}\text { Soil is the zone where plants take root, the foundation } \\
\text { for terrestrial life and the basis for a large amount of } \\
\text { economic production and varies in depth from a few } \\
\text { centimetres to several meters }\end{array}$ & UK & Environment Agency 2004 \\
\hline $\begin{array}{l}\text { Solid part of the earth, including the groundwater and } \\
\text { the other components and organisms that are present } \\
\text { in it }\end{array}$ & Belgium - Flanders & $\begin{array}{l}\text { Public Waste Agency of } \\
\text { Flanders (OVAM) } 2007\end{array}$ \\
\hline $\begin{array}{l}\text { Soil is generally defined as the top layer of the earth's } \\
\text { crust, formed by mineral particles, organic matter, } \\
\text { water, air and living organisms }\end{array}$ & EU & $\begin{array}{l}\text { European Commission } \\
\text { (EC) } 2006 b\end{array}$ \\
\hline $\begin{array}{l}\text { The top layer of the Earth's crust situated between the } \\
\text { bedrock and the surface. The soil is composed of } \\
\text { mineral particles, organic matter, water, air and living } \\
\text { organisms }\end{array}$ & EU & $\begin{array}{l}\text { Council of the European } \\
\text { Union } 2009\end{array}$ \\
\hline $\begin{array}{l}\text { (i) The unconsolidated mineral or organic material on } \\
\text { the immediate surface of the earth that serves as a } \\
\text { natural medium for the growth of land plants. }\end{array}$ & $\mathrm{N} / \mathrm{A}$ & $\begin{array}{l}\text { Soil Science Glossary } \\
\text { Terms Committee } 2008\end{array}$ \\
\hline $\begin{array}{l}\text { (ii)The unconsolidated mineral or organic matter on } \\
\text { the surface of the earth that has been subjected to } \\
\text { and shows effects of genetic and environmental } \\
\text { factors of: climate (including water and temperature } \\
\text { effects), and macro- and microorganisms, conditioned } \\
\text { by relief, acting on parent material over a period of } \\
\text { time. A product-soil differs from the material from } \\
\text { which it is derived in many physical, chemical, } \\
\text { biological, and morphological properties and } \\
\text { characteristics }\end{array}$ & & \\
\hline $\begin{array}{l}\text { (i) A dynamic natural body composed of mineral and } \\
\text { organic solids, gases, liquids, and living organisms }\end{array}$ & $\mathrm{N} / \mathrm{A}$ & Brady and Weil 2008 \\
\hline $\begin{array}{l}\text { (ii)The collection of natural bodies occupying parts of } \\
\text { the Earth's surface that is capable of supporting plant } \\
\text { growth and that has properties resulting from the } \\
\text { integrated effects of climate and living organisms } \\
\text { acting upon parent material, as conditioned by } \\
\text { topography, over periods of time }\end{array}$ & & \\
\hline
\end{tabular}




\begin{tabular}{|c|c|c|}
\hline State & Act & Reference \\
\hline $\begin{array}{l}\text { Belgium - } \\
\text { Franders }\end{array}$ & Soil Remediation Decree, 2006 & $\begin{array}{l}\text { Public Waste Agency of } \\
\text { Flanders (OVAM) } 2007\end{array}$ \\
\hline $\begin{array}{l}\text { Belgium- } \\
\text { Brussels }\end{array}$ & $\begin{array}{l}\text { Ordonnance du } 5 \text { mars } 2009 \text { relative à la gestion et à } \\
\text { l'assainissement des sols pollués }\end{array}$ & $\begin{array}{l}\text { Brussels Ministre de } \\
\text { l'Environnement } 2009\end{array}$ \\
\hline $\begin{array}{l}\text { Belgium- } \\
\text { Walloon }\end{array}$ & $\begin{array}{l}\text { Décret du } 5 \text { décembre } 2008 \text { relatif à la gestion des } \\
\text { sols }\end{array}$ & $\begin{array}{l}\text { Gouvernements de } \\
\text { communaute et de region- } \\
\text { Region Wallonne } 2009\end{array}$ \\
\hline Germany & Federal Soil Protection Law, 1998 & $\begin{array}{l}\text { Federal Ministry for the } \\
\text { Environment Nature } \\
\text { Conservation and Nuclear } \\
\text { Safety } 1998\end{array}$ \\
\hline Italy & $\begin{array}{l}\text { Ministerial Decree } 471 \text { on the remediation of polluted } \\
\text { sites, } 1999\end{array}$ & Governo Italiano 1999 \\
\hline Netherlands & Soil Protection Act, 1987 (Amended 2008) & $\begin{array}{l}\text { VROM (The Netherlands } \\
\text { Ministry of Housing, Physical } \\
\text { Planning and the Environment) } \\
1986\end{array}$ \\
\hline Spain & Royal Decree on contaminated soils, 2005 & $\begin{array}{l}\text { Spanish Central Government } \\
2005\end{array}$ \\
\hline Sweden & Environmental Code, 1999 & $\begin{array}{l}\text { Swedish Ministry of the } \\
\text { Environment } 1999\end{array}$ \\
\hline UK- England & Contaminated Land (England) Regulations 2006 & UK Government 2006 \\
\hline UK- N. Ireland & $\begin{array}{l}\text { The Waste and Contaminated Land (1997 Order) } \\
\text { (Commencement No. 6) Order (Northern Ireland) } \\
2002\end{array}$ & Northern Ireland Executive 2002 \\
\hline UK- Scotland & The Contaminated Land (Scotland) Regulations 2005 & The Scottish Government 2005 \\
\hline UK- Wales & Contaminated Land (Wales) Regulations 2006 & $\begin{array}{l}\text { National Assembly for Wales } \\
2006\end{array}$ \\
\hline
\end{tabular}

Table 3 Development of the definition of soil quality

\begin{tabular}{lcc}
\hline Soil Quality Definition & Year & Reference \\
\hline $\begin{array}{l}\text { The sustained capability of a soil to accept, store and recycle } \\
\text { water, nutrients and energy }\end{array}$ & 1984 & $\begin{array}{l}\text { Anderson and Gregorich } \\
1984\end{array}$ \\
$\begin{array}{l}\text { The state of existence of soil relative to a standard, or in terms } \\
\text { of a degree of excellence }\end{array}$ & 1991 & Larson and Pierce 1991 \\
$\begin{array}{l}\text { The capacity of a soil to function, within ecosystem and land use } \\
\text { boundaries, to sustain productivity, maintain environmental }\end{array}$ & 1994 & Doran and Parkin 1994 \\
\hline
\end{tabular}


quality, and promote plant and animal health

Ability of soil to perform or function according to its potential, and changes over time due to human use and management or to unusual events.

The capacity of a specific kind of soil to function, within natural or managed ecosystem boundaries, to sustain plant and animal productivity, maintain or enhance water and air quality, and support human health and habitation

Encompassing an indefinite (open) set of tangible or dispositional attributes of the soil. These attributes may be substituted for or supplemented by other attributes without needing to change the term. Therefore it is a vessel to contain what is assigned to it. The attributes assigned to the term will differ among soil and the various demands, because the term is influences by value judgements

1997 Karlen et al. 1997a

2000 Patzel et al. 2000

Table 4 Interaction between risk linkage, soil process, and soil properties

\begin{tabular}{|c|c|c|}
\hline Linkage & Process & Soil Properties \\
\hline \multirow{5}{*}{ 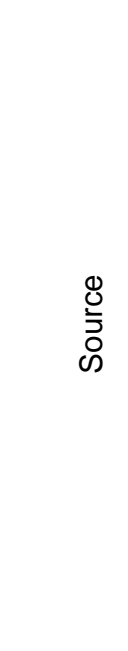 } & Leaching & $\begin{array}{l}\text { Cation exchange capacity, crop/ plant cover, soil texture, soil } \\
\text { permeability, soil organic matter, soil pH }\end{array}$ \\
\hline & $\begin{array}{l}\text { Ingestion of plant of } \\
\text { animal products }\end{array}$ & $\begin{array}{l}\mathrm{pH} \text {, soil texture, cation exchange capacity, soil organic matter, } \\
\text { porosity, bulk density, water content, hydraulic conductivity, soil } \\
\text { temperature }\end{array}$ \\
\hline & Direct ingestion & $\begin{array}{l}\mathrm{pH} \text {, cation exchange capacity, Fe- and } \mathrm{Mn} \text { oxide content, } \\
\text { particle size distribution, total organic and inorganic carbon, } \\
\text { water content, bulk density, porosity }\end{array}$ \\
\hline & Vapour transfer & $\begin{array}{l}\text { Total porosity of the unsaturated zone, water filled porosity } \\
\text { unsaturated zone, organic carbon fraction, soil dry bulk density, } \\
\text { soil permeability, moisture content, soil texture, soil temperature }\end{array}$ \\
\hline & Radon Exposure & $\begin{array}{l}\text { Radium concentration and its distribution in the soil, soil } \\
\text { porosity, permeability, moisture content }\end{array}$ \\
\hline \multirow[b]{2}{*}{ 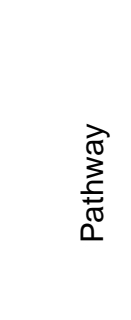 } & Wind erosion & $\begin{array}{l}\text { Soil erodible fraction, soil crust, soil roughness, soil texture, } \\
\text { bulk density, crop/ plant cover }\end{array}$ \\
\hline & $\begin{array}{l}\text { Migration, plant uptake } \\
\text { and volatilisation of } \\
\text { radio selenium }\end{array}$ & Soil redox status \\
\hline $\begin{array}{l}\frac{1}{0} \\
\frac{0}{0} \\
0 \\
0 \\
\mathbb{D}\end{array}$ & $\begin{array}{l}\text { Point or diffuse source } \\
\text { pollution (natural and } \\
\text { anthropogenic) }\end{array}$ & $\begin{array}{l}\text { Buffering capacity, soil microbes, ph and redox conditions, } \\
\text { occurrence of carbonates, Fe- and Al- hydroxides, inorganic } \\
\text { substances capable of chemisorptions, content and composition } \\
\text { of orgnanic substances, clay content and mineralogy, hydrolytic } \\
\text { acidity, cation exchange capacity, amount of exhangable bases } \\
\text { and exchangeable Al, soil texture }\end{array}$ \\
\hline
\end{tabular}




\section{References}

Acutis, M. and Donatelli, M. SOILPAR 2.00: software to estimate soil hydrological parameters and functions. Eur J Agron. 18:373-7; 2003.

Alexander, M. Agriculture's responsibility in establishing soil quality criteria. in: Environmental Improvement - Agriculture's challenge in the seventies. Washington, USA: National Academy of Sciences; 1971.

Alker, S.; Joy, V.; Roberts, P.; Smith, N. The Definition of Brownfield. J Environ Planning Manage. 43:49-69; 2000.

Alloway, B.J. 1994. Heavy metals in soils. USA: Springer.

Alvarez-Guerra, M.; Viguri, J.R.; Voulvoulis, N. A multicriteria-based methodology for site prioritisation in sediment management. Environ Int. 35:920-30; 2009.

Anderson, D.W. and Gregorich, E.G. Effect of soil erosion on soil quality and productivity. in soil erosion and degradation. In: Anonymous Proceedings of 2nd ann. Western Provincial Conf. Rationalisation of Water and Soil Research and Management. Saskatoon, Saskatchewan. Saskatchewan Institute of Pedology; 1984.

Appleton, J.D. Radon: sources, health risks, and hazard mapping. AMBIO. 36:85-9; 2007.

Arshad, M.A. and Cohen, G.M. Characterisation of soil quality physical and chemical criteria. Am J Alternative Agr. 7:12-6; 1992.

Ashton, D.; Benstead, R.; Bradford, P.; Whitehouse, P. An ecological risk assessment framework for contaminants in soil. UK: Environment Agency; 2008.

Ashworth, D.J. and Shaw, G. Soil migration, plant uptake and volatilisation of radioselenium from a contaminated water table. Sci Total Environ. 370:506-14; 2006.

Balasubramaniam, A.; Boyle, A.R.; Voulvoulis, N. Improving petroleum contaminated land remediation decision making through the MCA weighting process. Chemosphere. 66:791-8; 2007.

Barraclough, D. UK soil \& herbage pollutant survey: Project summary. UK: Environment Agency; 2007.

Beyer, W.N. and Connor, E. E. Gerould, S. Estimates of soil ingestion by wildlife. J Wildlife Manage. 58:375-82; 1994.

Bierkens, J. et al. Comparative sensitivity of 20 bioassays for soil quality. Chemosphere. 37:2935-47; 1998.

Blum, W. European Soil Protection Strategy. J Soils \& Sediments. 3:242; 2003. 
Blum, W. 1997. Basic concepts: Degradation, resilience and rehabilitation. In: Methods for assessment of soil degradation. Lal, R., Blum, W.H., Valentine, C., and others, editors. 1st ed. USA: CRC-Press. $1 \mathrm{p}$.

Blum, W.; Büsing, J.; de l'Escaille, T. European union soil thematic strategy. Brussels, Belgium: the European Commission, DG Environment; 2004a.

Blum, W.; Büsing, J.; Montanarella, L. Research needs in support of the European thematic strategy for soil protection. Trends Anal Chem. 23:680-5; 2004b.

Bogden, J.D. and Klevay, L.M. 2000. Clinical nutrition of the essential trace elements and minerals: The guide for health professionals. USA: Humana Press.

Bouma, J. Using soil survey data for quantitative land evaluation. Adv Soil Sci. 9:177213; 1989.

Boyd, C.E. 2000. Water quality: An introduction. USA: Springer.

Brady, N. and Weil, R. 2008. The nature and properties of soils. 14th ed ed. Upper Saddle River, NJ, USA: Prentice Hall.

Brimblecombe, P. 2001. Urban air pollution. In: The urban atmosphere and its effects. Brimblecombe, P. and Maynard, R., editors. UK: World Scientific.

Brussels Ministre de l'Environnement. Ordonnance du 5 mars 2009 relative à la gestionet àl'assainissementdes sols pollués. Brussels, Belgium: Brussels Ministre de l'Environnement; 2009.

Buol, S.W.; Southard, R.J.; Graham, R.C.; McDaniel, P.A. 2003. Soil genesis and classification. USA: Wiley Blackwell.

Burger, J.A. Limitations of bioassays for monitoring forest soil productivity: rationale and example. Soil Sci Soc Am J. 60:1674; 1996.

Burger, J.A. and Kelting, D.L. Using Soil Quality Indicators to Assess Forest Stand Management. Forest Ecol Manag. 122:155-66; 1999.

Burns, T.P.; Cornaby, B.W.; Hadden, C.T. Estimating Risk To Ecological Receptors From Contaminated Soil At Superfund Sites. Superfund Risk Assessment in Soil Contamination Studies: Second Volume :159; 1996.

Burton, G.A.; Chapman, P.; Smith, E.P. Weight-of-evidence approaches for assessing ecosystem impairment. Hum Ecol Risk Assess. 8:1657-73; 2002.

Calabrese, E.J.; Stanek, E.J.; James, R.C.; Roberts, S.M. Soil Ingestion: A Concern For Acute Toxicity In Children. Environ Health Perspect. 105:1354-8; 1997.

Calantone, R.; Di Benedetto, A.; Schmidt, J. Using the Analytic Hierarchy Process in New Product Screening. J Prod Innovat Manag. 16:65-76; 1999. 
Carey, P.D. et al. Countryside survey: UK results from 2007. UK: NERC/Centre for Ecology \& Hydrology; 2008.

Carter, M.R. Soil Quality for Sustainable Land Management: Organic Matter and Aggregation Interactions that Maintain Soil Functions. Agron J 94:38-47; 2002.

Carter, M.R.; Gregorich, E.G.; Anderson, J.W.; Doran, J.W.; Janzen, H.H.; Pierce, F.J. 1997. Concepts of soil quality and their significance. In: Soil quality of crop production and ecosystem health. Gregorich, E.G. and Carter, M.R., editors. Amsterdam, The Netherlands: Elsevier. 1 p.

Cave, M.; Chenery, S.; Shotbolt, L. Assessment of the soil contribution to atmospheric particulates in the UK- Source apportionment monitoring over days, years and decades.; 2009.

Chapman, P.M. Sediment quality criteria from the sediment quality triad: An example. Environ Toxicol Chem. 3:957-64; 1986.

Chapman, P.M.; McDonald, B.G.; Lawrence, G.S. Weight-of-evidence issues and frameworks for sediment quality (and other) assessments. Hum Ecol Risk Assess. 8:1489-515; 2002.

Chiou, C.T.; Sheng, G.Y.; Manes, M. A partition-limited model for the plant uptake of organic contaminants from soil and water. Environ Sci Technol. 35:1437-44; 2001.

Collins, C.; Fryer, M.; Grosso, A. Plant Uptake of Non-Ionic Organic Chemicals. Environ Sci Technol. 40:45-52; 2006.

Council of the European Union. Proposal for a directive of the european parliament and of the council establishing a framework for the protection of soil - progress report. Brussels, Belgium: Council of the European Union; 2010.

Council of the European Union. Proposal for a directive of the european parliament and of the council establishing a framework for the protection of soil - political agreement $=$ presidency proposal. Brussels, Belgium: Council of the European Union; 2009.

Cowherd, C.; Muleski, G.E.; Englehart, P.J.; Gillette, D.A. Rapid assessment of exposure to particulate emissions from surface contamination. U.S.A.: Environmental Protection Agency: Office of Health and Environmental Assessment; 1985.

Daily, G.C. Management objectives for the protection of ecosystem services. Environ Sci Policy. 3:333-9; 2000.

Darby, S. et al. Risk of lung cancer associated with residential radon exposure in south-west England: a case-control study. Br J Cancer. 78:394; 1998.

Daroussin, J. and King, D. Metadata: Pedotransfer rules database v.2.0 for environmental interpretations. In: Anonymous the use of pedotransfer in soil hydrology research in Europe, Workshop Proceedings Orleans, France. 1999. 
de Souza, M. Draft soil strategy for england and soil framework directive: A brief overview. In: Anonymous Proceedings of The future of Soil. London. 2009.

Department for Environment Food and Rural Affairs (DEFRA). Environmental standards for farming. consultation on proposed changes to standards in cross compliance good agricultural and environmental condition (GAEC) and related measures in england. UK: Department for Food and Rural Affairs (DEFRA); 2009.

Department for Environment Food and Rural Affairs (DEFRA). Consultation on a draft code of practice for the sustainable use of soils on construction sites. UK: Department for Food and Rural Affairs; 2008.

Department for Environment Food and Rural Affairs (DEFRA). Contaminated land report 7 (CLR7) - assessment of risks to human health from land contamination: An overview of the development of soil guideline values and related research. , UK. UK: Environment Agency; 2002.

Department for Food and Rural Affairs (DEFRA). Comparability of soil properties derived from different data sources. UK: Department for Food and Rural Affairs; 2003.

Department for International Development (DFID). A guide to environmental screening. UK: Department for International Development; 2003.

Department of Communities and Local Government (DCLG). Planning policy statement 25: Development and flood risk. UK: Department of Communities and Local Government; 2006.

Department of the Environment (DoE). The united kingdom national air quality strategy. London, UK: Stationary Office; 1997.

Dimas, S. and Gnacadja, L. Preface. In: European Commission ed. Climate changecan soil make a difference? Report on the conference Climate change - can soil make a difference? Brussels. Office for Official Publications of the European Communities; 2008.

Dirilgen, N.; Atay, N.A.Z.Z.; Tunc, H. Study of Efficiencies of Selected Extractants: SDS, lodide, Citric Acid in Soil Remediation from Lead. Soil Sediment Contam. 19:103-18; 2010.

Ditzler, C.A. and Tugel, A.J. Soil Quality Field Tools: Experiences of USDA-NRCS Soil Quality. Agron J. 94:33-8; 2002.

Doran, J.W. and Parkin, T.B. Quantitative Indicators of Soil Quality: A Minimum Data Set. SSSA Special Publication 49:25-38; 1996.

Doran, J.W. and Zeiss, M.R. Soil health and sustainability: managing the biotic component of soil quality. Appl Soil Ecol. 15:3-11; 2000.

Doran, J.W. and Parkin, T.B. 1994. Defining and assessing soil quality. In: Defining soil quality for a sustainable environment. Doran, J.W., Coleman, D.C., Bezdicek, D.F., 
and others, editors. 35, 3-21 (special publication) ed. USA: Soil Science Society of America.

Doran, J.W. and Werner, M.R. 1990. Management and soil biology. In: Sustainable agriculture in temperate zones. Francis, C.A., Flora, C.B.,King, L.D., editors. New York, USA: Wiley.

Duarte-Davidson, R. and Jones, K.C. Screening the environmental fate of organic contaminants in sewage sludge applied to agricultural soils: II. The potential for transfers to plants and grazing animals, Sci Total Environ. 185:59-70; 1996.

Earl, N. and Kearney, T. Methodology for comparison of human health risk assessment packages. In: Anonymous Contaminated Soil 2000: Proceedings of the Seventh International FZK/TNO Conference on Contaminated Soil Leipzig, Germany: Thomas Telford; 2000.

Elmore, J.G.; Armstrong, K.; Lehman, C.D.; Fletcher, S.W. Screening for Breast Cancer. J Am Med Assoc. 293:1245-56; 2005.

ENDS Europe. EU states aiming to water down soil directive. ENDS Report ; 2007.

Environment Agency. Environmental permitting regulations operational risk appraisal scheme (opra for EPR) version 3.4. UK: Environment Agency; 2009. .

Environment Agency. The state of soils in england and wales. UK: Environment Agency; 2004.

Environmental Change Network. ECN Soil Survey. 2009; 2009.

Environmental Protection Agency. Soil screening guidance: Technical background document. USA: Environmental Protection Agency; 1996.

European Chemicals Bureau. Technical guidance document on risk assessment: TGD part II. Brussels, Belgium: European Commission Joint Research Centre; 2002.

European Commission (EC). Soil protection: The story behind the strategy. Brussels, Belgium: European Commission; 2006a.

European Commission (EC). Communication from the commission to the council, the european parliament, the european economic and social committee and the committee of the regions. thematic strategy for soil protection COM(2006) 231. Brussels, Belgium: European Union; 2006b.

European Commission (EC). Proposal for a directive of the european parliament and of the council establishing a framework for the protection of soil and amending directive 2004/35/EC. Brussels, Belgium: European Commission; 2006c.

European Environment Agency. Indices of climate, soil and vegetation quality. Denmark: European Environment Agency; 2009. 
European Environment Agency (EEA). Environmental indicators: Typology and overview. Copenhagen, Denmark: European Environment Agency; 1999.

Evans, D.; Hers, I.; Wolters, R.M.; Boddington, R.T.B.; Hall, D.H. Vapour transfer of soil contaminants. Bristol, UK: Prepared by Golder Associates, Environment Agency; 2001.

Facchinelli, A.; Sacchi, E.; Mallen, L. Multivariate statistical and GIS-based approach to identify heavy metal sources in soils. Environ Pollut. 114:313-24; 2001.

Federal Ministry for the Environment Nature Conservation and Nuclear Safety. Federal soil protection and contaminated sites ordinance. Germany: Federal Ministry for the Environment Nature Conservation and Nuclear Safety; 1999.

Federal Ministry for the Environment Nature Conservation and Nuclear Safety. Federal soil protection act of 17 march 1998. Bonn, Germany: Federal Ministry for the Environment Nature Conservation and Nuclear Safety; 1998.

Fischer, M.L. et al. Factors Affecting Indoor Air Concentrations of Volatile Organic Compounds at a Site of Subsurface Gasoline Contamination. Environ Sci Technol. 30:2948-57; 1996.

Fleming, K.L.; Westfall, D.G.; Bausch, W.C. Evaluating management zone technology and grid soil sampling for variable rate nitrogen application. In: Anonymous Proceedings of the 5th International Conference on Precision Agriculture 2000.

Flemish Government. Order of the flemish government of 14 december 2007 establishing the flemish soil remediation and protection regulations. Belgium: Flemish Government; 2007.

Food and Agriculture Organisation (FAO). A framework for land evaluation. Rome, Italy: Food and Agriculture Organisation; 1976.

Fryrear, D.W.; Bilbro, J.D.; Saleh, A.; Schomberg, H.; Stout, J.E.; Zobeck, T.M. RWEQ: Improved wind erosion technology. J Soil Water Conserv. 55:183-9; 2000.

Fryrear, D.W.; Saleh, A.; Bilbro, J.D.; Schomberg, H.M.; Stout, J.E.; Zobeck, T.M. Revised wind erosion equation (RWEQ). Southern Plains Area Cropping Systems Research Laboratory,Wind Erosion and Water Conservation Research Unit, USDAARS; 1998.

Glasson, J.; Therivel, R.; Chadwick, A. 2005. Introduction to environmental impact assessment. Spon Pr.

Glazovskaya, M.A. Methodological guidelines for forecasting the geochemical susceptibility of soils to technogenic pollution. Netherlands: ISRIC - World Soil Information; 1990.

Gleick, P.H. Water conflict chronology. data from the pacific institute for studies in development, environment, and security database on water and conflict (water 

brief). USA: Pacific Institute for Studies in Development, Environment, and Security; 2008.

Glick, B.R. Changes in plant growth and development by rhizosphere bacteria that modify plant ethylene levels. Acta Horticult. 631:265-73; 2004.

Görlach, B.; Landgrebe-Trinkunaite, R.; Interwies, E.; Bouzit, M.; Darmendrail, D.; Rinaudo, J.D. Assessing the economic impacts of soil degradation. Berlin: Ecologic; 2004.

Gouvernements de communaute et de region- Region Wallonne. Décret relatif à la gestion des sols. Belgium: Moniteur Belge; 2009.

Governo Italiano. Ministerial decree 471. Italy: Gazzetta Ufficiale; 1999.

Hardisty, P.E. and Özdemiroğlu, E. 2005. The economics of groundwater remediation and protection. UK: CRC Press.

Harrison, R.M. and Hester, R.E. 2001. Assessment and reclamation of contaminated land: 16 (issues in environmental science and technology). UK: Royal Society of Chemistry.

Héry, M. et al. Effect of earthworms on the active methanotrophic bacteria community structure in a landfill biocover soil. ISME J. 2:92-104; 2008.

Hope, B.K. Examination of ecological risk assessment and management practices. Environ Int. 32:983-95; 2006.

Hung, $\mathrm{H}$. and Mackay, D. A novel and simple model of the uptake of organic chemicals by vegetation from air and soil. Chemosphere. 35:959-77; 1997.

Idowu, O.J. et al. Farmer-oriented assessment of soil quality using field, laboratory, and VNIR spectroscopy methods. Plant and Soil. 307:243-53; 2008.

Interdepartmental Group on Health Risks from Chemicals. Assessment of chemical carginogens: Background to general principles of a weight of evidence approach. UK: The Interdepartmental Group on Health Risks from Chemicals; 2002.

Jana, R.; Mohanty, B.P.; Springer, E.P. Multi-scale pedo-transfer functions for soil water retention. Vadose Zone J. 6:868-78; 2007.

Johnson, C.C. and Ander, E.L. Urban geochemical mapping studies: how and why we do them. Environ Geochem Health. 30:511-30; 2008.

Johnson, C.C.; Breward, N.; Ander, E.L.; Ault, L. G-BASE: Baseline geochemical mapping of Great Britain and Northern Ireland. Geochem Explor Environ Anal. 5:347-57; 2005.

Johnson, D.L. et al. Meaning of environmental terms. J Environ Qual. 26:581-9; 1997. 
1072

1073

1074

1075

Johnson, D.W.; Cole, D.W.; Gessel, S.P. Acid precipitation and soil sulfate adsorption properties in a tropical and in a temperate forest soil. Biotropica 11:38-42; 1979.

Jury, W.A.; Russo, D.; Streile, G.; El Abd, H. Evaluation of Volatilization by Organic Chemicals Residing Below the Soil Surface. Water Resour Res. 26:13-20; 1990.

Juvonen, R.; Martikainen, E.; Schultz, E.; Joutti, A.; Ahtiainen, J.; Lehtokari, M. A battery of toxicity tests as indicators of decontamination in composting oily waste. Ecotoxicol Environ Saf. 47:156-66; 2000.

Karlen, D.L.; Ditzler, C.A.; Andrews, S.S. Soil quality: why and how? Geoderma. $114: 145-56 ; 2003$.

Karlen, D.L.; Andrews, S.S.; Doran, J.W. Soil quality: Current concepts and applications. Adv Agron. 74:1-40; 2001.

Karlen, D.L.; Mausbach, M.J.; Doran, J.W.; Cline, R.G.; Harris, R.F.; Schuman, G.E. Soil quality: a concept, definition, and framework for evaluation. Soil Sci Soc Am J. 61:4-10; 1997a.

Karlen, D.L.; Mausbach, M.J.; Doran, J.W.; Kline, R.G.; Harris, R.F.; Schuman, G.E. Soil Quality: A concept, definition, and framework for evaluation. Soil Sci Soc Am J. 61:4-10; 1997b.

Lal, R. Soil degradation as a reason for inadequate human nutrition. Food Security. $1: 45-57 ; 2009$.

Lal, R. Soils and sustainable agriculture. A review. Agron Sustain Dev. 28:57-64; 2007.

Lal, R. Soil degradation by erosion. Land Degrad Dev. 12:519-39; 2001.

Lal, R. 1998. Soil quality and sustainability. In: Methods for assessment of soil degradation. Lal, R., Blum, W., Valentine, C., and others, editors. USA: CRC Press. $17 \mathrm{p}$.

Lal, R. Degradation and resilience of soils. Phil Trans R Soc Lond. 352:997-1010; 1997.

Lal, R. 1994. Sustainable land use systems and soil resilience. In: Soil resilience and sustainable land use. Greenland, D.J. and Szabolcs, I., editors. Wallingford: CAB International. $41 \mathrm{p}$.

Larson, W.E. and Peirce, F.J. 1994. The dynamics of soil quality as a measure of sustainable management. In: Defining soil quality for A sustainable environment. Doran, J.W., Coleman, D.C., Bezdicek, D.F., and others, editors. USA: Soil Science Society of America.

Larson, W.E. and Pierce, F.J. 1991. Conservation and enhancement of soil quality. In: Evaluation for sustainable land management in the developing world, vol. 2: Technical papers. International Board for Research and Management, editor. 
IBSRAM Proceedings No. 12(2) ed. Bangkok, Thailand: International Board for Research and Management.

Letey, J. et al. Deficiencies in the soil quality concept and its application. J Soil Water. Conserv 58:180-187; 2003.

Little, J.C.; Daisey, J.M.; Nazaroff, W.W. Transport of subsurface contaminants into buildings. Environ Sci Technol. 26:2058-66; 1992.

Loveland, P.J. and Thompson, T.R.E. Identification and development of a set of national indicators for soil quality. Bristol, UK: Environment Agency; 2002. .

MacEwan, R.J. and Carter, M.R. Advances in soil quality for land management: Science, practice and policy. In: Anonymous Proceedings of an International Symposium Centre for Environmental Management, University of Ballarat. Victoria, Australia: 1996.

Macleod, C. et al. Modelling human exposures to air pollution control (APC) residues released from landfills in England and Wales. Environ Int. 32:500-9; 2006.

Madejón, P.; Marañón, T.; Murillo, J.M.; Robinson, B. In defence of plants as biomonitors of soil quality. Environ Pollut. 143:1-3; 2006.

Massas, I.; Skarloub, V.; Haidouti, C. Plant uptake of 134Cs in relation to soil properties and time. J Environ Radioact. 59:245-55; 2002.

Mausbach, M.J. and Tugel, A.J. Soil quality and the Natural Resources Conservation. Agronomy Abst. 337; 1995.

McBratney, A.B.; Minasny, B.; Cattle, S.R.; Vervoort, R.W. From pedotransfer functions to soil inference systems. Geoderma. 109:41-73; 2002.

Merrington, G. et al. The development and use of soil quality indicators for assessing the role of soil in environmental interactions. UK: Environment Agency; 2006. .

Michaud, J.M.; Parsons, A.H.; Ripple, S.R.; Paustenbach, D.J. Human health risks associated with contaminated sites: Critical factors in the exposure assessment. In: Kostecki, P.T.; Calabrese, E.J.; Bell, C.C. eds. Hydrocarbon Contaminated Soils and Groundwater: Analysis, Fate, Environmental \& Public Health Effects, \& Remediation Newport Beach, California, USA. CRC Press; 1991.

Miles, J.C.H. and Appleton, J.D. Mapping variation in radon potential both between and within geological units. J Radiol Prot. 25:257-76; 2005.

Ministry of Agriculture, Fisheries and Food. Agricultural land classification of england and wales. London. UK: Ministry of Agriculture, Fisheries and Food; 1988. .

Montanarella, L. Towards protecting soil biodiversity in Europe: The EU thematic strategy for soil protection. Biodiversity. 9:76-7; 2008. 
Mostaghimi, S.; Brannan, K.M.; Dillaha, T.A.; Bruggeman, A.C. 2001. Best management practices for nonpoint source pollution control: Selection and assessment. In: Agricultural nonpoint source pollution: Watershed management and hydrology. Ritter, W.F. and Shirmohammadi, A., editors. USA: CRC Press.

Naidu, R.; Megharaj, M.; Dillon, P.; Kookana, R.; Correll, R.; Wenzel, W. 2006a. Point source pollution. In: Encyclopaedia of soil science. Lal, R., editor. USA: CRC Press.

Naidu, R.; Megharaj, M.; Dillon, P.; Kookana, R.; Correll, R.; Wenzel, W. 2006b. Nonpoint source pollution. In: Encyclopaedia of soil science. Lal, R., editor. USA: CRC Press.

Nathanail, C.P. and Bardos, R.P. 2004. Reclamation of contaminated land. UK: John Wiley and Sons.

National Assembly for Wales. Contaminated land (wales) regulations 2006 UK: The Stationery Office Limited; 2006.

Nazaroff, W.W. and Sextro, R.G. Technique for measuring the indoor radon-222 source potential of soil. Environ Sci Technol. 23:451-8; 1989.

Neung-Hwan, O. and Richter, D.D. Soil acidification induced by elevated atmospheric CO2. Glob Change Biol. 10:1936; 2004.

Northern Ireland Executive. Waste and contaminated land (1997 order) (commencement no. 6) order (northern ireland) 2002. UK: The Stationary Office; 2002.

Ó'Dochartaigh, B.; Fordyce, F.; Ander, E.L.; Bonsor, H. Groundwater and soil pollutants (GRASP): A screening tool applying soil geochemical data to assess threats to shallow groundwater in glasgow. William Smith Meeting, The Geological Society, London, UK 21-23 Sept 2009: British Geological Survey; 2009. .

Oldeman, L.R. Guidelines for general assessment of the status of human-induced soil degradation. Wageningen: International Soil Reference and Information Centre; 1988.

Pan, J.; Oates, C.J.; Ihlenfeld, C.; Plant, J.A.; Voulvoulis, N. Screening and prioritisation of chemical risks from metal mining operations, identifying exposure media of concern. . Environ Monit Assess. 1-17; 2009.

Patzel, N.; Sticher, H.; Karlen, D.L. Soil Fertility - Phenomenon and Concept. J Plant Nutr Soil Sc. 163:129-42; 2000.

Pierce, F.J. and Larson, W.E. Developing criteria to evaluate sustainable land management. In: Kimble, J.M. ed. Proc. Of the 8th Int. Soil Management Workshop: Utilization of Soil Survey Information for Sustainable Land Use Lincoln, WI, USA. USDA-SCS, National Soil Survey; 1993. 
Pierce, F.J. and Lal, R. 1992. Monitoring soil erosion's impact on soil productivity. In: Soil erosion research methods. Lal, R., editor. USA: Soil and Water Conservation Society.

Pollard, S.; Brookes, A.; Earl, N.; Lowe, J.; Kearney, T.; Nathanail, C.P. Integrating decision tools for the sustainable management of land contamination. Sci Total Environ. 325:15-28; 2004.

Pollard, S.; Yearsley, R.; Reynard, N.; Meadowcroft, I.C.; Duarte-Davidson, R.; Duerden, S.L. Current Directions in the Practice of Environmental Risk Assessment in the United Kingdom. Environ Sci Technol. 36:530-8; 2002.

Provoost, J.; Cornelis, C.; Swartjes, F. Comparison of Soil Clean-up Standards for Trace Elements Between Countries: Why do they differ? J Soils Sediments. 6:173$81 ; 2006$.

Public Waste Agency of Flanders (OVAM). Decree on soil remediation and soil protection. Belgium: Public Waste Agency of Flanders (OVAM); 2007. .

Quercia, F.; Marcomini, A.; Critto, A.; Carlon, C. Ecological risk assessment applied to contaminated sites: Review of international regulatory approaches and proposal of a national procedure. Rome, Italy: Italian National Agency for Environmental Protection; 2002.

Quevauviller, P. Water Protection Against Pollution. Conceptual framework for a science policy interface. Env Sci Pollut Res. 14:297-307; 2007.

Quevauviller, P. and Olazabal, C. Links between the water framework directive, the thematic strategy on soil protection and research trends with focus on pollution issues. J Soils Sediments. 4:243-4; 2003.

Rawlins, B.G.; Lark, R.M.; O'donnell, K.E.; Tye, A.M.; Lister, T.R. The assessment of point and diffuse metal pollution from an urban geochemical survey of Sheffield, England. Soil Use Manag. 21:353-62; 2005.

Rodrigues, S.M.; Pereira, M.E.; Ferreira da Silva, E.; Hursthouse, A.S.; Duarte, A.C. A review of regulatory decisions for environmental protection: Part I -- Challenges in the implementation of national soil policies. Environ Int. 35:202-13; 2009.

Romig, D.E. Farmer knowledge of soil health and its role in soil quality assessment. ; 1995.

Rutgers, M.; Bogte, J.J.; Dirven-Van Breemen, E.M.; Schouten, A.J. Locatiespecifieke ecologische risicobeoordeling - praktijkonderzoek met een kwantitatieve triadebenadering. The Netherlands: RIVM; 2001. .

Ryan, J.A.; Bell, R.M.; Davidson, J.M.; O'Connor, G.A. Plant Uptake of Non-ionic organic chemicals from soils. Chemosphere. 17:2299-323; 1988.

Saunier, R.E. and Meganck, R.A. 2009. Dictionary and introduction to global environmental governance. London: Earthscan. 
Schaap, M.G.; Leij, F.J.; van Genuchten, M.T. Rosetta: a computer program for estimating soil hydraulic parameters with hierarchical pedotransfer functions. J Hydrol. 251:163-76; 2001.

Schloter, M.; Dilly, O.; Munch, J.C. Indicators for evaluating soil quality. Agr Ecosyst Environ. 98:255-62; 2003.

Schoenholtz, S.H.; van Miegroet, H.; Burger, J.A. A review of chemical and physical properties as indicators of forest soil quality: challenges and opportunities. Forest Ecol Manag. 138:335-56; 2000.

Seybold, C.A.; Mausbach, M.J.; Karlen, D.L.; Rogers, H.H. 1998. Quantification of soil quality. In: Soil processes and the carbon cycle. Lal, R. and Stewart, B.A., editors. USA: CRC Press.

Shainberg, I. 2000. Interdisciplinary aspects of soil science. In: Handbook of soil science. Sumner, M.E., editor. CRC Press ed. USA.

Singer, A.C.; Jury, W.; Luepromchai, E.; Yahng, C.-.; Crowley, D.E. Contribution of earthworms to PCB bioremediation. Soil Biol Biochem. 33:765-76; 2001.

Singer, M.J. and Ewing, S.A. 2000. Soil quality. In: Handbook of soil sciences. Sumner, M.; ed. USA: CRC Press.

Sjöström, A.E.; Collins, C.D.; Smith, S.R.; Shaw, G. Degradation and plant uptake of nonylphenol (NP) and nonylphenol-12-ethoxylate (NP12EO) in four contrasting agricultural soils. Environ Pollut. 156:1284-9; 2008.

Soil Science Glossary Terms Committee. 2008. Glossary of soil science terms. USA: Soil Science Society of America.

Sojka, R.E. and Upchurch, D.R. Reservations Regarding the Soil Quality Concept. Soil Sci Soc Am J. 63:1039-54; 1999.

Sojka, R.E.; Upchurch, D.R.; Borlaug, N.E. Quality soil management or soil quality management: performance versus semantics. Adv Agron. 79:1-68; 2003.

Sombroek, W.G. and Sims, D. 1995. Planning for sustainable use of land resources: Towards a new approach. In: Land and water bulletin no. 2. Sombroek, W.G. and Sims, D., editors. 2nd ed. Rome, Italy: Food and Agriculture Organization.

Spanish Central Government. Royal decree (RD 9/2005) Spain: Boletín Oficial del Estado; 2005. .

Stenberg, B. Soil attributes as predictors of crop production under standardized conditions. Biol Fert Soils. 27:104-12; 1998.

Stewart, M.A.; Jardine, P.M.; Barnett, M.O.; Mehlhorn, T.L.; Hyder, L.K.; McKay, L.D. Heavy Metals in the Environment. Influence of Soil Geochemical and Physical Properties on the Sorption and Bioaccessibility of Chromium(III). J Environ Qual. 32:129-37; 2003a. 
Stewart, M.A. et al. Effects of Contaminant Concentration, Aging, and Soil Properties on the Bioaccessibility of $\mathrm{Cr}(\mathrm{III})$ and $\mathrm{Cr}(\mathrm{VI})$ in Soil. Soil Sediment Contam. 12:1-21; 2003b.

Suter, G. 2007. Ecological risk assessment. Second Edition ed. USA: CRC Press.

Suter, G.W. 2000. Ecological risk assessment for contaminated sites.USA: CRC.

Swedish Ministry of the Environment. The swedish environmental code. Sweden: Swedish Ministry of the Environment; 1999.

The Scottish Government. The contaminated land (scotland) regulations 2005. UK: The Stationary Office; 2005.

Thompson, K.M.; Burmaster, D.E.; Crouch, E.A.C. Monte Carlo Techniques for Quantitative Uncertainty Analysis in Public Health Risk Assessments. Risk Anal. 12:53-63; 1992.

Topp, E.; Scheunert, I.; Attar, A.; Korte, F. Factors affecting the uptake of C-14-labelled organic chemicals by plants from soil. Ecotoxicol Environ Saf. 11:219-28; 1986.

Torbert, H.A.; Daniel, T.C.; Lemunyon, J.L.; Jones, R.M. Relationship of Soil Test Phosphorus and Sampling Depth to Runoff Phosphorus in Calcareous and Noncalcareous Soils. J Environ Qual. 31:1380-7; 2002.

Trapp, S. and Matthies, M. Generic one-compartment model for uptake of organic chemicals by foliar vegetation. Environ Sci Technol. 29:2333-8; 1995.

Travis, C.C. and Arms, A.D. Bioconcentration of organics in beef, milk, and vegetation. . 22:271-274; 1988. Environ Sci Technol. 22:271-4; 1988.

UK Government. The contaminated land (england) regulations 2006. London, UK: The Stationery Office Limited; 2006.

UK Soil Indicators Consortium. Soil quality indicators for the soil functions of food and fibre production, ecological habitat and biodiversity, cultural heritage and conservation value. outputs from a meeting on the 13-14th february 2006 in Bath. UK: UK Soil Indicators Consortium; 2006.

Urusevskaya, I.S. Types of the vertical soil zonality and the soil-geographic zoning of mountain systems in Russia. Eurasian Soil Sci. 40:1145-57; 2007.

USDA- NRCS. Soil quality physical indicators: Selecting dynamic soil properties to assess soil function. soil quality- agronomy technical note. USA: United States Department of Agriculture; 2008.

van Geel, P.L.B.A. Letter setting out the new policy for soil. Netherlands: Netherlands Ministry of Housing, Spatial Planning and the Environment (VROM); 2003. 
van Straalen, N.M. and van Gestel, C.A.M. A stress ecology framework for comprehensive risk assessment of diffuse pollution. Sci Total Environ. 406:479-83; 2008.

Van-Camp, L.; Bujarrabal, B.; Olazábal, C. European soil policy thematic strategy on soil protection soil contamination. In: Anonymous Workshop Contaminated Land in Accession Countries Budapest. Joint Research Centre and the Directorate General Environment of the European Commission; 2003.

Van-Camp, L. et al. Reports of the technical working groups established under the thematic strategy for soil protection. Luxembourg: Office for Official Publications of the European Communities; 2004.

Várallya, G. Soil degradation processes and their control in Hungary. Land Degrad Dev. 1:171-88; 1989.

Voulvoulis, N. and Lester, J.N. Fate of organotins in sewage sludge during anaerobic digestion. Sci Total Environ. 371:373-82; 2006.

VROM (The Netherlands Ministry of Housing, Physical Planning and the Environment). Soil remediation circular. Netherlands: VROM (The Netherlands Ministry of Housing, Physical Planning and the Environment); 2009.

VROM (The Netherlands Ministry of Housing, Physical Planning and the Environment). Wet bodembescherming. Netherlands: Staatsblad van het Koninkrijk der Nederlanden; 1986.

Warkentin, B.P. and Fletcher, H.F. Soil quality for intensive agriculture. In: Anonymous Proceedings of the International Seminar on Soil Environment and Fertilizer Management in Intensive Agriculture Tokyo: Society for Science of Soil and Manure - National Institute of Agricultural Science; 1977.

Williams, G.M. and Aitkenhead, N. Lessons from Loscoe: the uncontrolled migration of landfill gas. Q J Eng Geol Hydroge. 24:191-207; 1991.

Wilson, S.C.; Duarte-Davidson, R.; Jones, K.C. Screening the environmental fate of organic contaminants in sewage sludges applied to agricultural soils: 1 . The potential for downward movement to groundwaters. Sci Total Environ. 185:45-57; 1996.

Winkler, R.; Ruckerbauer, F.; Bunzl, K. Radon concentration in soil gas: a comparison of the variability resulting from different methods, spatial heterogeneity and seasonal fluctuations. Sci Total Environ. 272:273-82; 2001.

Wood, C. 2003. Environmental impact assessment: A comparative review. Pearson Education. 